\title{
Türkiye'de İşsizlik Sigortası Ödeneği'nden Yararlanan İşsiz Sayısının Düşük Olma Nedenleri: AB Ülkeleri İle Bir Karşılaştırmalı Bir Analiz
}

Handan KUMAŞ, Department of Labor Economics and Industiral Relations, Pamukkale University, Turkey; email: hkumas@pau.edu.tr

Ŏguz KARADENIZ, Department of Labor Economics and Industiral Relations, Pamukkale University, Turkey;

e-mail:oguzk@pau.edu.tr

\section{The Causes for the Lower Number of Unemployed People Benefiting from Unemployment Insurance in Turkey: A Comparative Analysis with EU Countries}

\begin{abstract}
In Turkey The conditions the difficulty of utilization conditions, such as severance and notice compensation practices and informal employment can cause the number of beneficiaries of unemployment insurance to be low. Compare to EU member states, the coverage of unemployment insurance in Turkey is inadequate and the conditions for benefiting from it are heavy. The ratio of the unemployed benefiting from unemployment insurance to the total unemployed is about $10.5 \%$ in Turkey, but it is nearly $80 \%$ in Europe. This paper tries to explain why the number of unemployed people benefiting from unemployment insurance in Turkey is low compared to the EU. In the study, international comparisons were made using the EU MISSOC Comparative Tables Database. At the end of the study, it was found that the de facto coverage of unemployment insurance in Turkey is low, the atypical workers and the groups with high unemployment risk are heavy in terms of eligibility of unemployment insurance.
\end{abstract}

Keywords $\quad$ : Unemployment Insurance, Unemployment Benefits, Unemployment.

JEL Classification Codes : J33, J64, J65, J83.

Öz

Türkiye'de yararlanma koşullarının zorluğu, kıdem, ihbar tazminatı uygulamaları ve kayıt dışı istihdam gibi koşullar işsizlik sigortasından yararlananların sayısının düşük olmasına neden olmaktadır. AB ülkelerine göre, Türkiye'de işsizlik sigortasının kapsamı yetersiz ve yararlanma koşulları ağırdır. İşsizlik sigortasından yararlanan işsizlerin toplam işsizlere oranı Türkiye' de, yaklaşık $\% 10,5$ iken, Avrupa ülkelerinde \%80 civarındadır. Bu noktada çalışmanın amacı, AB ile karşılaştırmalı biçimde, Türkiye'de işsizlik sigortasından yararlanan sayısının neden düşük olduğunu açıklamaya çalışmaktır. Çalışmada ülkelerarası karşılaştırmalar, AB MISSOC Comparative Tables Database'den yararlanılarak yapılmıştır. Araştırma sonunda Türkiye'de işsizlik sigortasının filli kapsamının düşük olduğu, atipik çalışanların ve işsizlik tehlikesi yüksek grupların, işsizlik sigortasından yararlanma koşullarının ağır olduğu bulgularına ulaşılmıştır. 
Kumaş, H. \& O. Karadeniz (2017), “Türkiye'de İşsizlik Sigortası Ödeneği’nden Yararlanan İşsiz Sayısının

Düşük Olma Nedenleri: AB Ülkeleri İle Bir Karşılaştırmalı Bir Analiz”, Sosyoekonomi, Vol. 25(33), 195-220.

Anahtar Sözcükler : İşsizlik Sigortası, İşsizlik Ödeneği, İşsizlik.

\section{Giriş}

İstihdam, kişinin gelir ve sosyal güvenliğini (düzeyi ve koşulları tartışmaya açık olmakla birlikte) güvence altına alan bir durumdur. İşsizlik ise bireyin gelir ve sosyal güvenlikten yararlanmasını engelleyen en ciddi koşullardan birisidir. Bu bağlamda birçok ülke işsizliğin yarattığı olumsuz sonuçları ortadan kaldırmaya veya telafi etmeye yönelik önlemler almakta ve geliştirmektedir. Telafi edici en önemli önlemlerinden biri ise, işsizlik sigortasidir.

AB'nin yaklaşımı ile işsizlik sigortası: Bir kişinin gönülsüz biçimde işsiz kalması, istihdam kaydının olması ve aktif olarak iş araması durumunda hak kazandığı, çoğunlukla kamu harcamaları ile üstlenilen ve çalışan ve işverenin katkllarıla finanse edilen genellikle kazançla ilgili yardımları/ödemeleri içermektedir' ${ }^{1}$. ILO Dünya Sosyal Koruma Raporu'nda işsizlik sigortası; işsizlikle ilgili ödemeler, işsizlik parası düzenlemeleri olarak nitelenmiş ve işçilere gelir güvencesi sağlayan, geçici işsizlik durumunda işsizleri ve ailelerini destekleyen, yoksulluğun önlenmesine katkıda bulunan, ekonomideki yapısal değişim karşısında koruma sağlayan, kayıt dışı çalışmayı önleyen ve ekonomik krizlerde toplam talebin istikrara kavuşturulmasında kilit rol oynayan plan biçiminde betimlenmiştir (2014: XXII).

Lentz'göre (2008: 3) işsizlik sigortası dar anlamda; çoğunlukla çalışanın gönülsüz işsizliği durumunda ücret kaybına karşı sigortalandığı, işsizlik süresince en az geçim yolunu sağlayan ve bireyi istihdama döndürmeyi amaçlayan bir uygulama ve sigorta türüdür.

Yukarıdaki açıklamalar 1şığında işsizlik sigortası geniş anlamda; çoğunlukla isteği dışında işsiz kalan bireyin gelir kaybını (kısmen) önlemeyi ve satın alma gücünü korumayı amaçlayan, bireyin aktif olarak iş aramasını, piyasanın arz-talep dengesini ve sosyal korumayı sağlamaya yönelik olarak uygulanan, belirli miktarda prim, katkı payı ve sürelere göre ödenen, aktif ve pasif istihdam programları içinde yer alan bir sosyal sigorta uygulaması, sosyal politika ve işsizlikle mücadele aracı biçiminde tanımlanabilir.

İşsizlik sigortasının tarihsel akışı incelendiğinde, sanayi devrimi ve sosyal politikanın gelişim tarihine paralel olarak isteğe bağlı biçimde başlayan, 19. yüzyılın sonlarına doğru Almanya, İtalya ve İsviçre'de temel ekonomik güvenlik, bireysel refah ve bunlara bağlı koşulları sağlamak amacı ile hükümetler tarafından tasarlanan bir sosyal güvenlik uygulaması olduğu görülmektedir. İlk dönemlerde işsizlik sigortası, kamu ve kamu dışı olmak üzere iki sistem biçiminde yürütülmüştür. Zorunluluk esasına dayalı işsizlik sigortası

1 European Union Document and Publications, EU, Specific Terminology, <http://iate.europa.eu/FindTermsByLilId.do?lilId=1569447\&langId=en>, 02.03.2017. 
Kumaş, H. \& O. Karadeniz (2017), “Türkiye'de İşsizlik Sigortası Ödeneği'nden Yararlanan İşsiz Sayısının Düşük Olma Nedenleri: AB Ülkeleri İle Bir Karşılaştırmalı Bir Analiz”, Sosyoekonomi, Vol. 25(33), 195-220.

1911 yılında Birleşik Krallık tarafından Ulusal Sigorta Yasası bünyesinde oluşturulmuştur. İlgili yasa, ilk olarak ticaret sektöründe çalışanları kapsarken, daha sonra tüm çalışanları kapsayacak (bağımsız çalışanlar, tarım sektöründe ve ev işlerinde çalışanlar hariç) biçimde genişletilmiş ve sigorta kolu sistemin finansmanına işçi-işveren-devlet katkı yapacak biçimde düzenlenmiştir (Gordon, 1990: 228'den aktaran Başterzi, 1996: 62). Zorunlu işsizlik sigortası uygulamasında İngiltere'yi, Avusturya (1920) ve Almanya (1927) izlemiştir (Andaç, 2010: 53).

Türkiye'de işsizlik sigortasının 1950'li yıllardan 1999 yılına kadar tartışma evrimi içinde olduğu görülmektedir (Dilik, 2000: 2). İlk kez, Birinci Beş Yıllık Kalkınma Planı'nda (1963-1967) işsizlik sigortası önerisine yer verilmiştir. Altıncı Beş Yıllık Kalkınma Planı’nda (1990-1994) hazırlık çalışmalarının başlatılacağı, Yedinci Beş Yıllık Kalkınma Planı'nda ise sigortanın oluşturulacağı ve yasasının çıkartılması hedefleri konulmuştur. Sekizinci Beş Yıllık Kalkınma Planı'nın Amaç, İlkeler ve Politikalar başlığında “İşsizlik sigortası programının etkin bir şekilde uygulanması, oluşacak fonların fon yönetimi ilkeleri çerçevesinde değerlendirilmesi” esas alınmıştır (DPT, 2000: 109). Dokuzuncu Kalkınma Planı'nda, işsizlik sigortası ile ilgili bir amaç veya politika belirlenmezken, Onuncu Kalkınma Planı’nda İşgücü Piyasasının Etkinleştirilmesi Programı Başlığında, Ulusal İstihdam Stratejisi'ne paralel biçimde güvenceli esnekliğin sağlanmasına yönelik "Işsizlik sigortasından yararlanma koşullarının esnetilmesi ve yararlanma sürelerinin artırılması", amaçlanmıştır².

Sonuç olarak 1950'li yıllardan 1999'a yaklaşık 50 yıl tartışılan işsizlik sigortası 25.08.1999 tarihli 4447 Sayılı “İşsizlik Sigortası Yasası” ile kabul edilmiş ve 01.06.2000 tarihinden itibaren uygulanmaya başlanmıştır. Ancak yasanın işsizlik sigortasından yararlanma kapsamını ve sağlanan yardımları oldukça dar tutması, sosyal güvencesizliğe karşı beklenen faydanın gerçekleşememesine neden olmaktadır. Bu bağlamda, çalışmanın amacı, işsizlik sigortası fiili kapsamının yetersizliğinin nedenlerini AB ile karşılaştırmalı olarak incelemektir. Çalışmada kullanılan yöntem yazın taramasıdır. Ayrıca, işgücü istatistikleri betimsel istatistik yöntemi ile yorumlanmaya çalışıllmıştır.

Çalışmadan elde edilen bulgulara göre, Türkiye'de işsizlik sigortasından yararlanan işsizlerin toplam işsizlere oranı 2016 y1lı itibariyle yaklaşık \%10,5'dur (Bkz. Şekil 3). Oranın düşüklüğü, işsizlik sigortasının kapsamının yetersizliğine ve yararlanma koşullarının zorluğuna, kayıt dışı istihdam gibi işgücü piyasasından kaynaklanan sorunlarla bağlantılıdır. Türkiye'de işverenlerin bir kısmının kıdem ya da ihbar tazminatı ödememek, iş güvencesini uygulamamak için iş sözleşmesini işçi fesih etmiş (istifa) gibi göstermesi de işsizlik sigortasından yararlanmayı da zorlaştırabilmektedir.

2 T.C. Kalkınma Bakanlı̆̆ı, 2013, Onuncu Beş Yıllık Kalkınma Planı 2014-2014, Ankara, 〈http://www.kalkinma.gov.tr/Lists/Kalknma\%20Planlar/Attachments/12/Onuncu\%20Kalk\%C4\%B1nma\%20P lan\%C4\%B1.pdf>, 12.12.2016. 
Kumaş, H. \& O. Karadeniz (2017), “Türkiye'de İşsizlik Sigortası Ödeneği’nden Yararlanan İşsiz Sayısının

Düşük Olma Nedenleri: AB Ülkeleri İle Bir Karşılaştırmalı Bir Analiz”, Sosyoekonomi, Vol. 25(33), 195-220.

\section{AB Ülkeleri ile İşsizlik Tehlikesine Karşı Geliştirilen Sosyal Güvence Sistemleri}

Dünya'da, işsizlik tehlikesine karşı geliştirilen sosyal güvenlik programları iki ana başlıkta sınıflandırılabilir: Birincisi primlerle finanse edilen işsizlik sigortası programları, ikincisi ise vergilerle finanse edilen iş arama yardımı ya da işsizlik yardımı programlarıdır. İşsizlik sigortası, çalışırken işsiz kalanları koruma altına alan; işsizlik yardımı ise daha çok işgücü piyasasına yeni girmiş veya daha önce prim ödemediği için işsizlik sigortasından yararlanamayan işsizleri kapsayan programlardır. İşsizlik sigortasının kapsamı, bağlanma koşulları, süresi, miktarı, zorunlu ve isteğe bağlı olması ülkelerin işsizlik geçmişi ve işsizlik oranı, işsizliğe bakış açısı gibi nedenlerden dolayı farklılık göstermektedir. Uygulamada da işsizlik sigortası ve yardımını almayı güçleştiren koşullar bulunmaktadır. Özellikle ekonomik krizler, bir yandan işsizlik sigortası ve yardımını almayı güçleştirirken, diğer yandan kapsamının genişletilmesine de neden olmaktadır. Dünya Bankası'nın 2013 İş Raporu'nda kriz süresince işsizlerin sadece \%15,4'ünün işsizlikle ilgili ödemelerden yararlanabildiği ve izleyen süreçte OECD'ye üye 23 ülke ve Orta Avrupa ve Latin Amerika ülkelerinde işsizlik yardımlarının süresinin uzatıldığı vurgulanmıştır (The World Bank, 2013: 62). ILO'nun 2012 yılı analizine göre, son ekonomik kriz dikkatleri işsizlik sigortasına çekmiştir. Ancak 200 ülkenin yarıdan daha azı işsizler için koruma sağlarken, Dünya çapındaki işçilerin \%70'den fazlası işsizlik sigortası ve herhangi bir işsizlik yardımından yararlanamamaktadır (ILO, 2012).

İşsizlik sigortası öncelikle işçileri korumaya yönelik bir sigorta türüdür. Ancak, işsizlik tehlikesi sadece işçiler için değil, memur, diğer bağımlı çalışanlar ve işverenler için de geçerlidir. MISSOC (Mutual Information System on Social Protection) Karşılaştırmalı Tablosu'nda (2016) yer alan 32 ülkenin tamamında işçiler işsizlik sigortası kapsamında iken; mevcut durumda Romanya, Litvanya, Slovenya, Danimarka ve Hırvatistan olmak üzere sadece beş ülkede memurlar ve 15 ülkede zorunlu veya gönüllü olmak üzere bağımsız/kendi hesabına çalışanlar işsizlik sigortasından yararlanabilmektedir (Tablo 1).

MISSOC verilerine göre Bulgaristan'da 2009-2014 döneminde kamu çalışanları işsizlik sigortası kapsamında yer almıştır: Her takvim ayında 40 saat veya beş günden daha fazla çalışanlar ve benzer grup çalışanları (örneğin memurlar, seçimle gelen çalışanlar, hakimler, askerler ve askeri personel, din görevlileri); kooperatiflerin ücretli ve aktif üyeleri; ticari şirket yöneticileri işsizlik sigortası kapsamındadır. Ancak, 2015 yılındaki düzenleme ile kamu çalışanları ve din görevlileri kapsam dışı bırakılmıştır (MISSOC, 2015). 2016 yılında çalışanlar ve benzeri gruplar için işsizlik sigortasından yararlanmada belirli bir süre/saat çalışma koşulu aranmamış, şirket yöneticilerinin yanı sıra şirketlerin temsilcilerine, tüccarlara, yönetim kurulu üyelerine zorunlu ve denizde çalışanlara isteğe bağlı işsizlik sigortası olanağı getirilmiştir (MISSOC, 2016). 
Tablo: 1

Avrupa Ülkeleri Örnekleri İle Zorunlu ve İsteğe Bağlı İșsizlik Sigortasının Kapsamı

\begin{tabular}{|c|c|c|c|c|c|c|c|c|c|c|c|c|c|c|c|c|c|c|c|c|c|c|c|c|}
\hline \multirow[b]{2}{*}{ ÜLKELER } & \multicolumn{4}{|c|}{ İşçiler } & \multicolumn{4}{|c|}{ Bağımsız Çalışanlar } & \multicolumn{4}{|c|}{ Mesleki Eğitim Görenler } & \multicolumn{4}{|c|}{ Memurlar } & \multicolumn{4}{|c|}{ Tüm İşsizleri Kapsayan Isșsizlik Yardımı } & \multicolumn{4}{|c|}{ İsteğe Bağh İşsizlik Sigortası } \\
\hline & సิे & 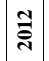 & กิ & ๙ิ & ڤે̀ & 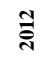 & $\stackrel{n}{\widetilde{\pi}}$ & 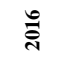 & ڤ્సે & ิㅡㄹ & $\stackrel{n}{\tilde{N}}$ & ํํำ & 今ิ & ิㅗㄱ & 䎏 & ำ & ڤิે & בัป & $\stackrel{\sim}{\bar{\pi}}$ & ํํำ & స్తి & ิㅡำ & ำ & ลั \\
\hline Belçika & $\mathrm{x}$ & $\mathrm{x}$ & $\mathrm{x}$ & $\mathrm{x}$ & & & & & $\mathrm{x}$ & $\mathrm{x}$ & & & & & & & & & & & & & & \\
\hline İsviçre & $\mathrm{x}$ & $\mathrm{x}$ & $\mathrm{x}$ & $\mathrm{x}$ & & & & & & & & & & & & & & & & & & & & \\
\hline Çek Cumhuriyeti & $\mathrm{x}$ & $\mathrm{x}$ & $\mathrm{x}$ & $\mathrm{x}$ & $\mathrm{x}$ & $\mathrm{x}$ & $\mathrm{x}$ & $\mathrm{x}$ & & & & & & & & & & & & & & & & \\
\hline Danimarka & $\mathrm{x}$ & $\mathrm{x}$ & $\mathrm{x}$ & $\mathrm{x}$ & $\mathrm{x}$ & $\mathrm{x}$ & $\mathrm{x}$ & $\mathrm{x}$ & $\mathrm{x}$ & $\mathrm{x}$ & $\mathrm{x}$ & $\mathrm{x}$ & $\mathrm{x}$ & $\mathrm{x}$ & $\mathrm{x}$ & $\mathrm{x}$ & & & & & $\mathrm{x}$ & $\mathrm{x}$ & $\mathrm{x}$ & $\mathrm{x}$ \\
\hline Almanya* & $\mathrm{x}$ & $\mathrm{x}$ & $\mathrm{x}$ & $\mathrm{x}$ & $\mathrm{x}$ & $\mathrm{x}$ & $\mathrm{x}$ & $\mathrm{x}$ & $\mathrm{x}$ & $\mathrm{x}$ & $\mathrm{x}$ & $\mathrm{x}$ & & & & & $\mathrm{x}$ & $\mathrm{x}$ & & & $\mathrm{x}$ & $\mathrm{x}$ & $\mathrm{x}$ & $\mathrm{x}$ \\
\hline Estonya & $\mathrm{x}$ & $\mathrm{x}$ & $\mathrm{x}$ & $\mathrm{x}$ & & & & & & & & & & & & & $\mathrm{x}$ & $\mathrm{x}$ & $\mathrm{x}$ & $\mathrm{x}$ & & & & \\
\hline İspanya** & $\mathrm{x}$ & $\mathrm{x}$ & $\mathrm{x}$ & $\mathrm{x}$ & & & $\mathrm{x}$ & $\mathrm{x}$ & & & & & & & & & & & & & & $\mathrm{x}$ & $\mathrm{x}$ & $\mathrm{x}$ \\
\hline Fransa $* * * *$ & $\mathrm{x}$ & $\mathrm{x}$ & $\mathrm{x}$ & $\mathrm{x}$ & & & & & & & & & & & & & $\mathrm{x}$ & $\mathrm{x}$ & $\mathrm{x}$ & $\mathrm{x}$ & $\mathrm{x}$ & $\mathrm{x}$ & $\mathrm{x}$ & $\mathrm{x}$ \\
\hline Izlanda & $\mathrm{x}$ & $\mathrm{x}$ & $\mathrm{x}$ & $\mathrm{x}$ & $\mathrm{x}$ & $\mathrm{x}$ & $\mathrm{x}$ & $\mathrm{x}$ & & & & & & & & & & & & & & & & \\
\hline Italya $* * * * *$ & $\mathrm{x}$ & $\mathrm{x}$ & $\mathrm{x}$ & $\mathrm{x}$ & & & & & & & & & & & & & & & & & & & & \\
\hline Macaristan & $\mathrm{x}$ & $\mathrm{x}$ & $\mathrm{x}$ & $\mathrm{x}$ & $\mathrm{x}$ & $\mathrm{x}$ & $\mathrm{x}$ & $\mathrm{x}$ & & & & & & & & & & & & & & & & \\
\hline Hollanda• & $\mathrm{x}$ & $\mathrm{x}$ & $\mathrm{x}$ & $\mathrm{x}$ & & & & & & & & & & & & & & & & & & $\mathrm{x}$ & $\mathrm{x}$ & $\mathrm{x}$ \\
\hline Avusturya॰• & $\mathrm{x}$ & $\mathrm{x}$ & $\mathrm{x}$ & $\mathrm{x}$ & $\mathrm{x}$ & $\mathrm{x}$ & $\mathrm{x}$ & $\mathrm{x}$ & $\mathrm{x}$ & $\mathrm{x}$ & $\mathrm{x}$ & $\mathrm{x}$ & & & & & & & & & $\mathrm{x}$ & $\mathrm{x}$ & $\mathrm{x}$ & $\mathrm{x}$ \\
\hline Polonya & $\mathrm{x}$ & $\mathrm{x}$ & $\mathrm{x}$ & $\mathrm{x}$ & & & & & & & & & & & & & & & & & & & & \\
\hline Portekiz & $\mathrm{x}$ & $\mathrm{x}$ & $\mathrm{x}$ & $\mathrm{x}$ & & & & $\mathrm{x}$ & & & & & & & & & & & & & & & & \\
\hline Romanyaø.•• & $\mathrm{x}$ & $\mathrm{x}$ & $\mathrm{x}$ & $\mathrm{x}$ & $\mathrm{x}$ & $\mathrm{x}$ & $\mathrm{x}$ & $\mathrm{x}$ & & & & & $\mathrm{x}$ & $\mathrm{x}$ & $\mathrm{x}$ & $\mathrm{x}$ & & & & & $\mathrm{x}$ & $\mathrm{x}$ & $\mathrm{x}$ & $\mathrm{x}$ \\
\hline Birleșik Krallık $\uparrow$ & $\mathrm{x}$ & $\mathrm{x}$ & vy• & $\mathrm{x}$ & & & & & & & & & & & & & & & & & & & & \\
\hline Irlanda & $\mathrm{x}$ & $\mathrm{x}$ & $\mathrm{x}$ & $\mathrm{x}$ & & & & & & & & & $\mathrm{x}$ & $\mathrm{x}$ & $\mathrm{x}$ & $\mathrm{x}$ & $\mathrm{x}$ & $\mathrm{x}$ & $\mathrm{x}$ & $\mathrm{x}$ & & & & \\
\hline Hirvatistan & vy & vy & $\mathrm{x}$ & $\mathrm{x}$ & - & - & $\mathrm{x}$ & $\mathrm{x}$ & & & & & - & - & $\mathrm{x}$ & $\mathrm{x}$ & & & & & & & & \\
\hline Lüksemburg \pm & $\mathrm{x}$ & $\mathrm{x}$ & $\mathrm{x}$ & $\mathrm{x}$ & $\mathrm{x}$ & $\mathrm{x}$ & $\mathrm{x}$ & $\mathrm{x}$ & & & & & & & & & & & & & & & & \\
\hline TÜRKIYY & $\mathrm{x}$ & $\mathrm{x}$ & $\mathrm{x}$ & $\mathrm{x}$ & & & & $x>>$ & & & & $\mathrm{x}]$ & & & & & & & & & $\mathrm{x}$ & $\mathrm{x}$ & $\mathrm{x}$ & $\mathrm{x}$ \\
\hline \multicolumn{25}{|c|}{ 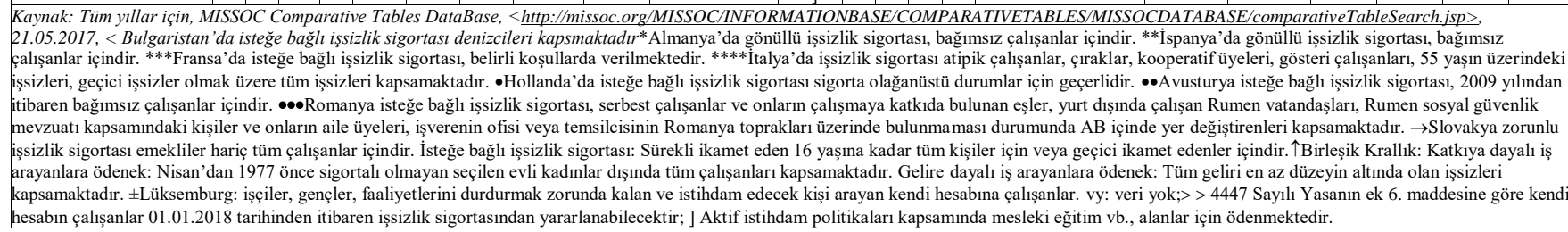 } \\
\hline
\end{tabular}


Mevcut durumda Romanya, Avusturya, Almanya, Danimarka ve İspanya'da gönüllü, Hırvatistan, Çek Cumhuriyeti, Finlandiya, Macaristan, İzlanda, Lüksemburg, Portekiz, Slovenya, İsveç ve Norveç zorunlu olmak üzere kendi hesabına çalışanlar ve Bulgaristan'da işverenler işsizlik sigortası kapsamındadır (Tablo 1) ${ }^{3}$. Eski Doğu Bloku ülkelerinde işsizlik sigortası kapsamının geniş olması, tek işverenin Devlet olduğu ve zorunlu çalışmadan dolayı işsizliğin olmadığı “Güdümlü Işsgücü Piyasası”nın izleri ile açıklanabilir. Eski Demir Perde ülkelerinin dışında Avusturya'da, isteğe bağlı işsizlik sigortası her çalışanı kapsamamakta, bu uygulamadan 1 Ocak 2009'dan itibaren sadece bağımsız çalışanlar yararlanmaktadır (MISSOC, 2016).

Portekiz zorunlu işsizlik sigortası kapsamının geniş olduğu, özellikle serbest çalışanların da kapsam altına alındığı ülkelerden biridir. 2016 MISSOC verilerine göre, iş sözleşmesi ile işe alınmayan ve belirlenen şema kapsamındaki tüm çalışanlar işsizlik sigortasından yararlanmaktadır. Genel sisteme göre söz konusu çalışanlar: Çalışmaya uygun engelli işsizler, belirli koşullarda eski askeri üyeler, ticaret ya da ticaretle uğraşan bireysel girişimciler gibi bazı serbest meslek sahipleri; bireysel limited şirketlerin sahipleri; aktif şirket ortakları, tüzel kişiliklerin yasal organlarının üyeleri ve faaliyetinin en az \%80'nini sözleşme yaptığı kuruluş adına gerçekleştiren serbest meslek sahipleridir.

Kapsam açısından değerlendirildiğinde çalışanlar dişında işsizlik sigortasından yararlanan diğer bir grup, mesleki eğitim alanlardır. Almanya, Avusturya, Danimarka'da mesleki eğitim alanlar yararlanma koşullarına bağlı olarak işsizlik sigortası ödeneği alabilmektedirler. Örneğin; Avusturya'da tüm ücretli çalışanlar ve mesleki/iş eğitimi alanlar, mesleki iyileştirme eğitimine katılanlar zorunlu işsizlik sigortası kapsamındadır. Ayrıca, Avusturya'da bir kişinin aylık geliri 415,72 Euro'nun altında (2016 yılı için eşik gelir) ise zorunlu işsizlik sigortası primi yükümlülüğü bulunmamaktadır.

MISSOC 2016’ya göre Almanya'da zorunlu işsizlik sigortası, genç engellileri ve mesleki eğitim alan kişileri de içerecek biçimde mavi ve beyaz yakalı tüm çalışanları kapsamaktadır.

İşsizlik sigortasının en etkili ve etkin biçimde uygulandığg ülkelerden biri, Danimarka'dır. Bu ülkede sistem, 1990'ların başından itibaren yararlanma sayısı ve süresi açısından çok iyi uygulanmaktadır ve işsizlik yardımlarını dışında kalmak çok az görülen bir durumdur (Lentz, 2008: 6). Danimarka'da çalışanların \%80'inden fazlası sistemin üyesidir, yardım sistemi gönüllüğe dayanmakta ve işçi katılmaya karar verirse, sigorta primi ödemektedir. 2015 tarihi itibari ile Danimarka'da işsizlik sigortası fonuna üye olan, ülkede ikamet eden 18-63 yaş arası: 
Kumaş, H. \& O. Karadeniz (2017), “Türkiye'de İşsizlik Sigortası Ödeneği’nden Yararlanan İşsiz Sayısının

Düşük Olma Nedenleri: AB Ülkeleri İle Bir Karşılaştırmalı Bir Analiz”, Sosyoekonomi, Vol. 25(33), 195-220.

- Çalışanlar,

- En az 18 aylık mesleki eğitimini tamamlamış, mesleki eğitimini veya eğitimini tamamladıktan sonra en geç 2 hafta içinde fonda kaydı olanlar,

- Askerlik görevini yapanlar,

- Bağımsız çalışan ve yardımcı eşi,

- Kamu görevi yürütenler (meclis üyeleri gibi) veya belediyede çalışanları,

- İşsizlik sigortasından yararlanmaktadırlar (MISSOC; 2009, 2012, 2015).

MISSOC 2016 Temmuz verilerine göre, Danimarka'da 832 Sayılı Birleştirme Yasası (Temmuz 2015) ile geniş kapsam sürdürülmüş ancak yaş aralığı ve 18 yaş altındaki bireyler için koşullar değiştirilmiştir. 2016 yılına göre, Danimarka'da ikamet eden işsizlik sigortası üyesi, 18-62 yaş arası kişiler ve 18 yaşın altında en az 18 aylık mesleki eğitimi tamamlayanlar, işsizlik sigortasından yararlanabilmektedir.

Danimarka örneğinde olduğu gibi işsizlik sigortası gönüllü/isteğe bağlı olarak da uygulanabilmektedir. İsteğe bağlı işsizlik sigortası Bulgaristan, Almanya, İspanya, Fransa, Hollanda, Finlandiya, Slovakya ve Türkiye'de görülmektedir. Örneğin Romanya'da; belirli koşullarla belirli grupların isteğe bağlı işsizlik sigortası primi ödemeyebilmesi mümkündür. Zorunlu işsizlik sigortası Romanya'da ikamet eden işçiler ve benzerleri, memurlar için uygulanırken, bağımsız çalışanlar ve katkıda bulunan eşleri, yurtdışında çalışan Romanya vatandaşları ve işverenlerinin ofisi veya temsilcilikleri Romanya topraklarında olmayan AB sınırları içinde dolaşan Romanya sosyal güvenlik sisteminde kayıtlı olan bir kişi ve ailesi için isteğe bağlı rejim bulunmaktadır (MISSOC, 2016).

Almanya'da 1 Şubat 2006'dan itibaren belirli gruptaki kişiler, kendi istekleri ile işsizlik sigortasının gönüllü olarak devamını sağlayabilmektedir (Sosyal Şartnamenin 28a. Bölümü, III. Kitab-III): Haftada en az 14 saat aile üyelerine bakanlar, haftada en az 15 saat bağımsız çalışanlar, AB üyesi veya ilişkili ülkeler dışında istihdam edilenler, isteğe bağlı işsizlik sigortasından yararlanabilmektedirler Almanya'da isteğe bağlı işsizlik sigortasına başvurabilecek kişilerin, son 24 ay içinde 12 ay zorunlu sigorta kapsamında olması ya da işe girmeden önce SGB (Sozialgesetzbuch) III'e göre işsizlik yardımı alması gerekmektedir. Almanya'da zorunlu işsizlik sigortası ödeneklerinin bitmesinden/kesilmesinden sonra iş arayanlara, temel güvenlik avantajları sağlanmaktadır. Temel güvenlik avantajı; iş arayanlara yönelik yapılan yardım, işsizlik sigortası yardımlarının SGB III'e göre sona ermesinden sonra veya ek yardımların veya gelirin ihtiyaçları karşılamak için yeterli olmaması durumunda çalışabilecek tüm yararlanıcılar ve aile bireylerine temel güvenlik kazancı sağlamayı ifade etmektedir (MISSOC, 2016).

Almanya örneğine benzer biçimde diğer $\mathrm{AB}$ ülkelerinde de işsizlere, işsizlik sigortası dışında, zorunlu sigorta koşullarının sağlanmaması veya ödeneklerin bitmesine rağmen işsizliğin devam etmesi durumunda işsizlik yardımları yapılmaktadır. Örneğin, Finlandiya'da işsizlere, işsizlik sigortası ve işsizlik yardımı ödenekleri verilmektedir. İşsizlik sigortası temel işsizlik ödeneği ve kazanca bağlı işsizlik ödeneği olmak üzere iki 
Kumaş, H. \& O. Karadeniz (2017), “Türkiye'de İşsizlik Sigortası Ödeneği’nden Yararlanan İşsiz Sayısının Düşük Olma Nedenleri: AB Ülkeleri İle Bir Karşılaştırmalı Bir Analiz”, Sosyoekonomi, Vol. 25(33), 195-220.

biçimde uygulanmaktadır. Temel işsizlik ödeneğinden 17-64 yaş arasında istihdam edilenler ile kendi hesabına çalışanlar yararlanırken; kazanca bağlı işsizlik ödeneğinden işsizlik sigortası fonu üyesi olan 17-64 yaş arasında istihdam edilenler ile kendi hesabına çalışanlar yararlanmaktadır. Finlandiya'da işsizlik yardımından yararlanmak için işsiz kişinin üç koşulu sağlaması gerekmektedir: İlk koşul, işsizin işsizlik sigortası programının tüm koşullarını tamamlayamaması veya en uzun süre ile günlük ödeme alması durumudur. İkinci koşul; 18-24 yaş arasında olmak, iş teklifini veya iş eğimini geri çevirmemek ve mesleki eğitim başvurusunda ihmalde bulunmamaktır. Üçüncü koşul ise sadece işgücü piyasası önlemleri sırasında olmak koşulu ile mesleki eğitimini tamamlamayan 17 yaşında bir işsiz (stajyer/çırak, işgücü piyasasına ilişkin mesleki eğitim alan veya rehabilite edilenler, deneme süresinde olanlar) olmaktır (MISSOC, 2016).

Çeşitlilik içeren işsizlik yardımlarının uygulandığı diğer bir ülke, İtalya'dır. İtalya'da işsizler "İstihdam Sosyal Ödeneği, Hareketlilik Ödeneği ve Kazanca Göre Ek Ödenek”'lerden yararlanabilmektedirler. Örneğin; tüm işçi ve benzerleri, çıraklar, kooperatif üyeleri ve gösteri sanatları-işleri ile uğraşanlar, atipik çalışanlar istihdam sözleşmesi ile çalışanlar ve yarı zamanlı çalışanlar İstihdam Sosyal Ödeneği kapsamındadırlar. İnşaat sektöründe çalışanlar dışında tüm çalışanlar hareketlilik ödeneği alabilirken, geçici işsizlik durumunda tüm çalışanlar için olağan ve olağanüstü tamamlayıcı kazanç ödemeleri yapılmaktadır (MISSOC, 2016). Ayrıca, İtalya'da 2016 yılında Yeni Sosyal Sigorta uygulamaları kapsamında yapılan değişiklik ile belirtilen kişiler dışında, 55 yaşın üzerinde mevcut durumda işsiz olanlar da işsizlik sigortasından yararlanabilmektedir (MISSOC, 2016).

İşsizlere farklı tür ve koşullarda yardım yapılan bir diğer ülke İspanya'dır. İspanya'da işsizlere Ödenek Yardımı ve Aktif Entegrasyon Gelirleri ödenmektedir. Katkıya dayalı işsizlik yardımının bitmesi durumunda, aile yükümlülükleri olan veya aile yükümlülükleri olmayan 45 yaş üstü işsizler, prim koşullarını sağlayamayan (belli koşullar altında: katkı payı/süresi ve aile sorumlulukları) işsizler; belirli koşullar altında 55 yaş üzerinde işsiz olanlar; yurtdışından geri dönen göçmen işçiler, cezaevinden tahliye olanlar, malullük ve emeklilik aylığı durdurulanlar işsizlik yardımına hak kazanmaktadırlar. Ayrıca İspanya'da işsizlik yardımı ve ödeneğine hak kazanamayan 65 yaşın altında, 45 yaşın üstündeki uzun süreli işsizler, belirli koşullar altında yurtdışından dönen göçmen işçiler, engelli kişiler, aile içi şiddete ve cinsiyetçi baskıya uğrayan kişiler Aktif Entegrasyon Geliri (Renta Activa de Inserción, RAI)'nden yararlanmaktadır (MISSOC, 2016). İspanya'da işsizlik yardımı ve ödeneği biten ancak işsiz olan kişiler, Profesyonel Yeniden Niteliklendirme Programı ve İstihdamı Aktifleştirme Programları'ndan yararlanmaktadır. Yukarıda söz edilen program ve uygulamalar, işsizlik tehlikesine karşı tüm nüfusun koruma altına alınmaya çalışıldığının bir göstergesi olmaktadır.

MISSOC 2016 verilerine göre; işsizlik yardımları Estonya, Fransa, Birleşik Krallık (gelir testi) ve İrlanda'da vergiler ile finanse edilirken, Finlandiya ve Portekiz'de katkı ve vergilerle finanse edilmektedir. Danimarka'da isteğe bağlı işsizlik sigortası ödemeleri katkı ve vergiler ile yapılmaktadır. Finlandiya'da temel işsizlik ödeneği ile isteğe bağlı işsizlik 
Kumaş, H. \& O. Karadeniz (2017), “Türkiye'de İşsizlik Sigortası Ödeneği'nden Yararlanan İşsiz Sayısının Düşük Olma Nedenleri: AB Ülkeleri İle Bir Karşılaştırmalı Bir Analiz”, Sosyoekonomi, Vol. 25(33), 195-220.

ödenekleri katkı ve vergilerle finanse edilmektedir. Almanya'da “İş Arayanlar için Temel Güvenlik Yardımları” vergiler ile ödenmektedir.

Yukarıda söz edilen AB uygulamaları birlikte değerlendirildiğinde Türkiye’de işsizlik sigortası kapsamanın sınırlı olduğu görülebilmektedir (Tablo 1). Aynı zamanda Türkiye'deki işsizlerin ciddi bir bölümü işsizlik sigortasının yapısından dolayı ödenekten yararlanamamaktadır. Bu noktada aşağıdaki başlıklarla, AB ülkeleri ile karşılaştırılarak Türkiye'de işsizlik sigortasının uygulanmasını güçleştiren koşullara değinilecektir.

\section{Türkiye’de İşsizlik Sigortası: Kapsam ve Yararlanma Koşulları}

\section{1. İşçilere Yönelik Koșullar}

Uzun bir evrimleşme dönemi sonunda uygulama başlanan işsizlik sigortası, yaşlılık aylığı almak için yaş şartını yükselten emeklilik reformu ile birlikte hayata geçirilmiştir. Dolayısıyla işsizlik sigortası ile bir anlamda, çalışanların emeklilik yaşının yükselmesine yönelik tepkilerinin azaltılmasının da amaçlandığı söylenebilir. İşsizlik sigortasından temel olarak 5510 sayılı Yasa'nın 4. maddesinin 1/a bendinde yer alan işçiler yararlanmaktadır (Güzel \& Okur \& Caniklioğlu, 2016: 672). İşsizlik sigortasından yararlanmak için işçinin kendi isteği ve kusuru dışında işsiz kalması ve Yasa'da belirtilen prim ödeme gün sayılarını doldurmas1 gereklidir.

4447 sayılı İşsizlik Sigortası Yasasına göre, işsizlik sigortası edimlerinden yararlanabilmek için sigortalının işsiz kalmadan önceki son üç yıl içinde en az 600 gün, işsiz kalmadan önceki son 120 gün de kesintisiz prim ödenmesi gerekmektedir (4447 sayılı Kanun m.51).

İşsizlik sigortasından sigortalıya dört temel edim verilmektedir. Bunlardan birincisi ve en önemlisi, işsize işsizlik ödeneği verilmesidir. Kişi işsiz kalmadan önceki son üç yılda 600 gün işsizlik sigortası primi ödemiş ise, 180 gün, 900 gün işsizlik sigortası primi ödemiş ise 240 gün, 1080 gün prim ödemiş ise 300 gün ișsizlik sigortası ödeneği alacaktır. İşsizlik ödeneği işsiz kalmadan önceki son dört aylık kazanç ortalamasının \%40’dır. İşsizlik ödeneği tavanı ise asgari ücretin brüt tutarının \%80'ini geçememektedir (4447 sayılı Kanun m.50). 2017 yılı itibariyle asgari ücretin brüt 1.777,50 TL olduğu dikkate alındığında belirtilen yıl için işsizlik ödeneği alt sınırı 711, üst sınırı ise 1.422 TL olarak hesaplanmaktadır.

İşsizlik sigortasından sağlanan ikinci edim, işsiz kalan sigortalının işsizlik ödeneği aldığı süre boyunca sağlık primlerinin işsizlik sigortası fonundan karşılanmasıdır. Üçüncü edim, işsize iş bulmasında yardımcı olunması, dördüncüsü ise; işsiz kalan işsizin yeniden iş bulmasını kolaylaştıracak mesleki eğitimden geçirilmesidir (aktif işgücü hizmetleri ve kurs ve programları) (4447 sayılı Kanun m.48).

\subsection{Kendi Adına ve Hesabına Çalışanlara Yönelik Koşullar}

08.03.2017 tarihinden önce kendi nam ve hesabına çalışanlar esas olarak işsizlik sigortasının kapsamı dışında tutulmuşlardır. 6824 sayılı yasa ile 4447 sayılı Yasa'ya eklenen 
Kumaş, H. \& O. Karadeniz (2017), “Türkiye'de İşsizlik Sigortası Ödeneği’nden Yararlanan İşsiz Sayısının

Düşük Olma Nedenleri: AB Ülkeleri İle Bir Karşılaştırmalı Bir Analiz”, Sosyoekonomi, Vol. 25(33), 195-220.

6. madde ile Esnaf Ahilik Sandı̆̆ kurulmuştur. Düzenleme ile 5510 sayılı Yasanın 4. maddesinin birinci fikrasının (b) bendi kapsamında iş sözleşmesi bağlı olmaksızın kendi adına ve hesabına bağımsız çalışanlar Esnaf Ahilik Sandığı kapsamında, Esnaf Ahilik Sandığı sigortalısı sayılmıştır. 5510 sayılı Yasa'nın 50. maddesi kapsamındaki; isteğe bağlı sigortalılar, jokey ve antrenörler, köy ve mahalle muhtarları ile tarımsal faaliyette bulunanlar (çiftçiler) ise Yasa'nın kapsamı dışında tutulmuştur.

Esnaf Ahilik Sandığı'ndan sağlanan edimler ve koşulları işsizlik sigortası fonundan işçilere sağlanan edimler ile neredeyse aynıdır. Bununla beraber, Esnaf Ahilik Sandığı ödeneğinden yararlanabilmek için iflas istemiyle mahkemeye başvurmuş olmak ya da işyerini kapatmak suretiyle sigortalılığı sona erenlerin, sigortalılı̆̆ının sona erdiği tarihi izleyen günden itibaren otuz gün içinde Kuruma doğrudan veya elektronik ortamda başvurma ve yeni bir iş almaya hazır olduklarını kaydettirme zorunlulukları vardır (4447 sayılı Yasa ek madde 6). İşçilerden farklı olarak sigortalıların ödenekten yararlanabilmek için 90 günden fazla prim borcu bulunmaması gerekmektedir. Bununla birlikte, prim borçlarını taksitlendirenler de söz konusu ödenekten yararlanabilecektir (4447 sayılı Yasa ek madde 6). Esnaf Ahilik Sandığı uygulaması 01.01.2018 tarihinde yürürlüğe girecektir (6824 sayılı Yasa m.25/c).

\section{Türkiye'de İşsizlik Sigortasından Yararlanmayı Güçleştiren Koşullar}

\section{1. İşsizlik Sigortasının Kapsamının Yetersizliği}

4447 Sayılı Yasa'nın 46. maddesine göre işsizlik sigortası; "5510 sayılı Sosyal Sigortalar ve Genel Sağlık Sigortası Yasası'nın 4 üncü maddesinin birinci fikrasının (a) bendi ile ikinci fikrası kapsamında olanlardan bir hizmet akdine dayalı olarak çalışan sigortalıları ve 506 sayılı Sosyal Sigortalar Yasası'nın geçici 20. maddesinde açılanan sandıklara tabi sigortalıları" kapsamaktadır. Yasa sadece "iş sözleşmesine bağlı" bağımlı çalışanlar ile kendi sosyal sigorta sandıklarını kurmuş olan banka, sigorta şirketi, ticaret ve sanayi odalarında iş sözleşmesi ile çalışanları da kapsam altına almıştır (Güzel \& Okur \& Caniklioğlu, 2016: 672). 5510 sayılı yasanın 4. maddesinin b fikrasına göre sigortalı sayılanlar (kendi hesabına çalışanlar, şirket ortakları, çiftçiler), c fikrasında sayılan memurlar ve 5. maddesi uyarınca kısmen sigortalı sayılan ve kısa vadeli sigorta kollarına tabi tutulanlar ise işsizlik sigortasının kapsamı dışında tutulmuşlardır. (Güzel \& Okur \& Caniklioğlu, 2016: 674). Söz konusu grup içinde ceza ve infaz kurumları ile tutukevleri bünyesindeki atölye ve tesislerde çalışan hükümlü ve tutuklular, 3308 sayılı Meslekî Eğitim Yasası'nda belirtilen aday çırak, çırak ve işletmelerde meslekî eğitim gören öğrenciler meslek liselerinde okumakta iken veya yükseköğrenimleri sırasında zorunlu staja tabi tutulan öğrenciler ile 2547 sayılı Yükseköğretim Yasası'nın 46. maddesine tabi olarak yarı zamanlı çalıştırılan öğrenciler, harp malulleri ve vazife malulleri, Türkiye İş Kurumu tarafından düzenlenen meslek edindirme, geliştirme ve değiştirme eğitimine katılan kursiyerler, Türkiye ile sosyal güvenlik sözleşmesi olmayan ülkelerde iş üstlenen işverenlerce yurt dışındaki işyerlerinde çalıştırılmak üzere götürülen Türk işçileri yer almaktadır (Bkz. 5510 sayılı Kanun m.5). 
5510 sayılı Yasaya göre (m. 6) sosyal sigortalı sayılmayan oldukça geniş diğer çalışan grupları da diğer sosyal sigorta kollarında olduğu gibi işsizlik sigortasının kapsamı dışında kalmaktadırlar (Güzel \& Okur \& Caniklioğlu, 2016: 674). Ayrıca, işverenin ücretsiz çalışan eşi, aynı konut içinde aile içinde yapılan işlerde çalışanlar, ev hizmetlerinde gündelik çalışanlar, tarım sektöründe özel sektörde süreksiz iş sözleşmesi ile çalışanlar, düşük gelirli esnaf ve sanatkârlar 5510 sayılı yasa kapsamı dışında tutuldukları için işsizlik sigortasından da yararlanamamaktadırlar. Ayrıca, Türkiye'de istihdamda ücretli çalışma dışında kendi hesabına çalışma ve ücretsiz aile iş̧̧iliği de yaygındır. Tarımda kendi hesabına çalışma $\% 41$, ücretsiz aile iş̧̧iliği ise $\% 47^{\prime}$ dir. Sanayide kendi hesabına çalışma oranı $\% 7,5$, inşaatta $\% 10,8$ iken hizmet sektöründe \%12'ye yükselmektedir (Şekil 1). Ücretli istihdam dışında istihdam biçimleri düzensiz, geçici ya da düzensiz ücretlidir.

Şekil: 1

\section{İstihdamın Sektörlere ve İşteki Duruma Göre Dağılımı (2016 Yılı) (\%)}

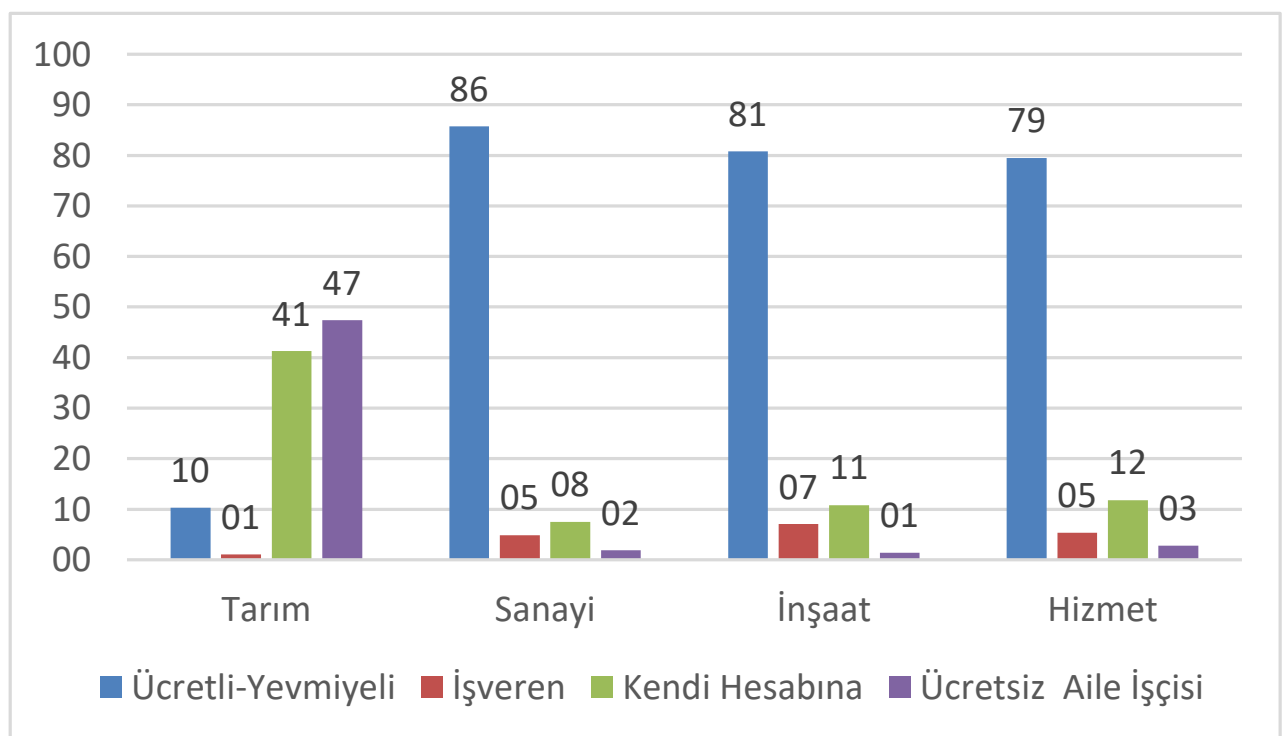

Kaynak: TÜIK, İşücü İstatistikleri 2016’dan oluşturulmuştur, <http://tuik.gov.tr/PreTablo.do?alt_id=1007>, 15.02.2016.

Sosyal sigorta sisteminin tarımda kendi hesabına çalışan düşük gelirli çiftçiler, tarımda yevmiyeli çalışanlar ile düşük gelirli esnaf ve sanatkarı kapsam dışı bırakması, sosyal sigortanın kapsamını daraltmakta ve özellikle atipik çalışan kadınları olumsuz yönde etkilemektedir. (Karadeniz, 2011/a).

Söz konusu grupların çoğu zaman prim ödeme güçlerinin olmadığı ya da prim tahsilatının zor olacağı gerekçeleri ile sosyal sigorta rejiminin kapsamı dışında tutuldukları söylenebilir. Eğreti çalışanların sosyal sigorta kapsamı dışında tutulması işsizlik sigortası kapsamının daralmasına neden olmaktadır. 


\section{Şekil: 2}

\section{İşsizlik Sigortası Kapsamına Giren ve Girmeyen Gruplar}

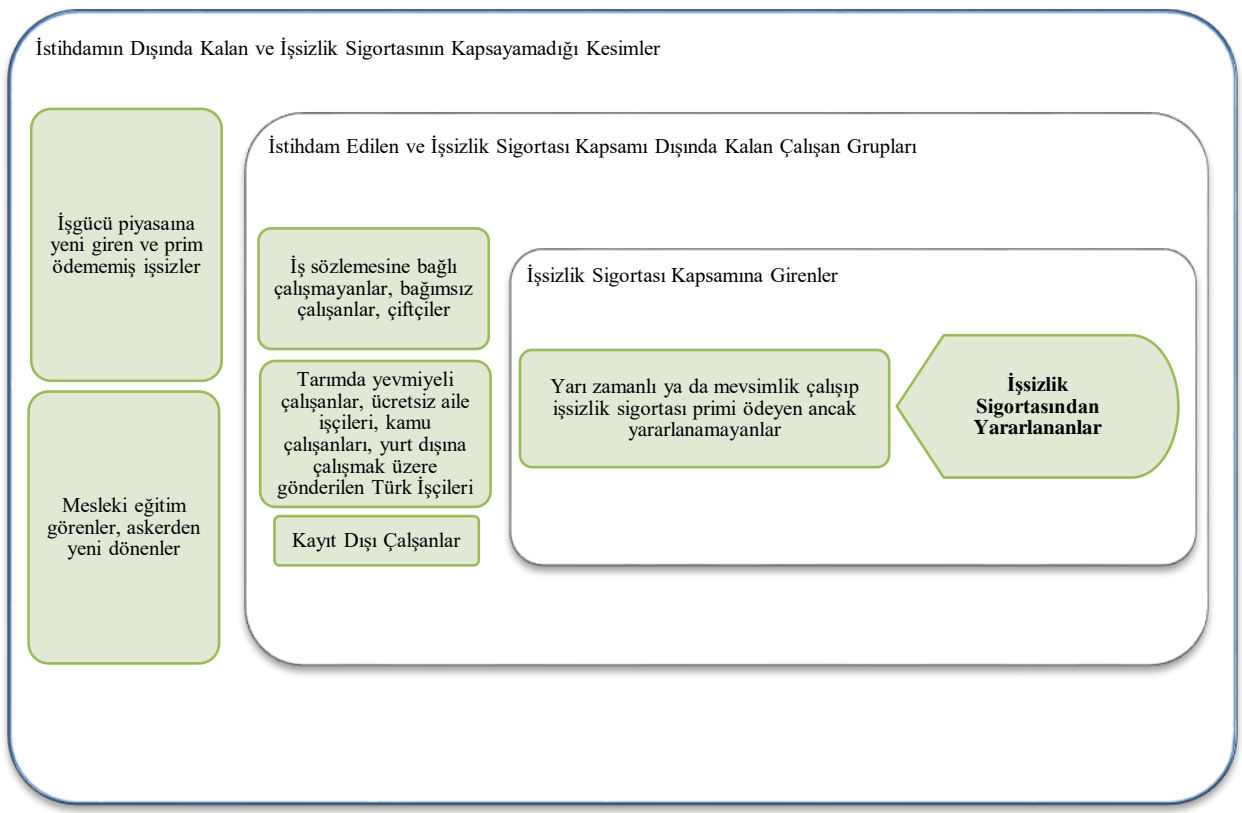

Kaynak: Çalışma kapsamında 5510 ve 4447 sayılı Yasalardan yararlanılarak yazarlar tarafindan oluşturulmuştur.

İşgücü piyasasına yeni girmiş işsizler, kendi hesabına çalışanlar, ücretsiz aile işçileri, yarı zamanlı çalışanlar, kayıt dışı çalışanlar da dikkate alındığında işsizlik sigortasından yararlanabilecek çalışan grubu ciddi biçimde daralmaktadır (Şekil 2).

İşsizlik sigortası kapsamını daraltan bir diğer neden, iş sözleşmesinin sonlanma koşullarıdır. İşçinin ödenekten yararlanabilmesi için kendi isteği ve kusuru dışında işsiz kalmaması gereklidir. Bir başka anlatımla, iş sözleşmesini nedensiz olarak kendisi sona erdiren (istifa eden) işçiler ile İş Yasası'nın 25/II maddesi uyarınca Ahlak ve Iyi Niyet Kurallarına Aykırıllı̆ $l$ nedeni ile işveren tarafindan sona erdirilen işçiler de işsizlik ödeneğine hak kazanamamaktadır (IŞKUR, 17.05.2016).

\subsection{Fiili Kapsamının Yetersizliği (İşsizlik Ödeneği Alanların Toplam İşsizlere Oranı): Avrupa Ülke Örnekleri ile Karşılaştırma}

ILO'ya göre ise 2009 yllında küresel boyutta 78 ülkede işsizlere yönelik işsizlik sigortası ve/veya yardımı gibi yasal koruma sağlanmış ve Dünya'daki toplam işsizlerin $\% 13$ 'ü bu tür yasal korumadan yararlanmıştır (ILO, 2009). Ancak, 2014 verileri ile yasal korumadan yararlanan işsizlerin oran1, \%12'ye düşmüştür (ILO, 2014: XXI). ILO 2014/15 Dünya Sosyal Koruma Raporu'na göre ise Dünya genelinde işgücünün sadece \%28'i mevcut 
mevzuatların (primli-primsiz yararlanma) koşullarını sağlayarak potansiyel olarak işsizlikle ilgili ödemelerden yararlanabilmektedir. Ayrıca, işsizlikle ilgili ödemelerden yararlananların sayısı dengeli dağılmamakta ve bölgesel farklılıklar bulunmaktadır. İşü̈cünün Avrupa'da \%80'i, Latin Amerika'da \%38'i, Ortadoğu'da \%21'i, Asya ve Pasifik Bölgesi'nde \%17'si ve Afrika'da \%8'i işsizlikle ilgili yardımları alabilecek koşullara sahiptir (ILO, 2014: XXI). Ayrıca, Dünya genelinde işsizlerin \%12'si, Batı Avrupa ülkelerinde yaklaşık \%64'ü, Asya ve Pasifik'te \%7'nin biraz üzeri, Latin Amerika ve Karayip'lerde \%5 ve Orta Doğu ve Afrika'da \%3'den daha az işsiz, işsizlik sigortası ödeneği/işsizlik yardımına hak kazanmaktadır (ILO, 2014: XXII). 2011 yılı verilerine göre tüm işsizlerin Avusturya'da \%94'ü, Almanya'da \%88'i Avustralya'da \%69'u, Danimarka'da \%77'si, Fransa'da \%56'sı, Birleşik Krallık'ta \%61'i koruma altındayken, Türkiye'de AB ülkeleri ile karşılaştırıldığında işsizlik sigortasının kapsadığı işsiz oranı 2012 yılı itibariyle sadece \% 7,7'olup, yetersizdir (Bkz. Tablo 2).

Tablo: 2

\section{Ülke Örnekleri ile İşsizlik Sigortası Ödeneği ve/veya Yardımlarından} Yararlananların Toplam İşsizlere Oranı (2013)

\begin{tabular}{|c|c|c|c|c|c|c|c|}
\hline Ülkeler & 2007 & 2008 & 2009 & 2010 & 2011 & 2012 & 2013 \\
\hline Arnavutluk & 7,8 & 6,7 & 6,3 & 6,4 & 6 & 6,9 & \\
\hline Andorra & & & & 8,3 & 10 & & 11,1 \\
\hline Arjantin & 4,3 & 5,6 & & & 4,9 & & \\
\hline Ermenistan & & & 30,5 & & & 15,8 & \\
\hline Avustralya & 62,4 & 65,8 & 58,2 & 51,3 & 51,4 & 52,7 & \\
\hline Avusturya & 89,8 & 90,4 & 91,3 & 91,4 & 90,5 & & \\
\hline Azerbaycan & & & 6,6 & & & 2,5 & \\
\hline Bahamalar & 0 & 0 & & & 18,8 & 25,7 & \\
\hline Bahreyn & & & 7,9 & & & & \\
\hline Belarus & 54 & 46,6 & 49,4 & 44 & 46,1 & & \\
\hline Belçika & 86,1 & 85,7 & 83,6 & 82,8 & 83,1 & 80,2 & \\
\hline Bosna Hersek & 1,6 & 1,6 & 2,4 & 2,6 & 2 & & \\
\hline Bulgaristan & 27,1 & 44,8 & 45,6 & 30,8 & 28,4 & & 25,6 \\
\hline Kanada & 44,5 & 43,6 & 48,4 & 46,1 & 41,8 & 39,1 & 40,5 \\
\hline Şili & 19,6 & 19,5 & & & 23,7 & 27,5 & 29,9 \\
\hline Çin & & & 14 & & & & \\
\hline Hurvatistan & 22,5 & 24,2 & 26,2 & 25,9 & 24,4 & & 20 \\
\hline Kibris & 81,5 & 81,2 & 79,1 & 78,7 & & & \\
\hline Çekya & 31,5 & 42,7 & 40,4 & 30,8 & 25,8 & 20,5 & 21,2 \\
\hline Fildişi Sahili & 0 & 0 & 0 & 0 & 0 & 0 & 0 \\
\hline Danimarka & 77,8 & 72 & 78,6 & 70,9 & 48,3 & 72 & 77,2 \\
\hline Estonya & 25,9 & 31,6 & 45,1 & 35,2 & 25,7 & 27,6 & \\
\hline Finlandiya & 58,8 & 57,5 & 47,9 & 52,1 & 57,8 & 59,1 & \\
\hline Fransa & 67,4 & 67,2 & 66 & 62,3 & 59,8 & 58,2 & 56,2 \\
\hline Almanya & 80,6 & 86,1 & 86,4 & 87,6 & 86,3 & 88 & \\
\hline Yunanistan & 53,9 & 58 & 57,7 & 43,1 & & & \\
\hline Hong Kong & & & 16,9 & & & & \\
\hline Macaristan & 42,6 & 41,3 & 48 & 39,5 & 35,7 & 31,4 & \\
\hline İzlanda & 39,1 & 49,8 & 17,7 & 21,6 & 28,6 & & \\
\hline İlanda & 85,9 & 0 & 91,3 & 87,2 & 21,6 & & \\
\hline İsrail & & & 38,2 & 36,3 & & 29,4 & \\
\hline İtalya & 42,5 & 43,9 & 61,3 & 56,2 & 55,8 & & \\
\hline Japonya & & & 25,4 & 19,6 & & & \\
\hline Kazakistan & & & 1 & 0,5 & & & \\
\hline Kore Cumhuriyeti & & & 39,2 & 36 & & 45,5 & \\
\hline Kırgızistan & & & 1,4 & 1,2 & & 0,9 & \\
\hline Letonya & 47 & 34,8 & 33,4 & 27,9 & 20,8 & 19,5 & \\
\hline Litvanya & & & & & & 21,5 & \\
\hline Lüksemburg & & & & & & 43,8 & \\
\hline Madagaskar & 0 & 0 & 0 & 0 & 0 & 0 & 0 \\
\hline Malawi & 0 & 0 & 0 & 0 & 0 & 0 & 0 \\
\hline Malezya & 0 & & 0 & 0 & & & 0 \\
\hline Maldivler & 0 & & 0 & 0 & & & 0 \\
\hline
\end{tabular}


Kumaş, H. \& O. Karadeniz (2017), “Türkiye'de İşsizlik Sigortası Ödeneği’nden Yararlanan İşsiz Sayısının Düşük Olma Nedenleri: AB Ülkeleri İle Bir Karşılaştırmalı Bir Analiz”, Sosyoekonomi, Vol. 25(33), 195-220.

\begin{tabular}{|c|c|c|c|c|c|c|c|}
\hline Mali & 0 & 0 & 0 & 0 & 0 & 0 & 0 \\
\hline Marşal Adaları & 0 & 0 & 0 & 0 & 0 & 0 & 0 \\
\hline Moritanya & 0 & 0 & 0 & 0 & 0 & 0 & 0 \\
\hline Mauritius & 0,9 & 0,9 & 0,9 & 1,1 & 1,2 & & \\
\hline Meksika & 0 & 0 & 0 & & 0 & 0 & 0 \\
\hline Moldova Cumhuriyeti & & & & & & 11,4 & \\
\hline Moğolistan & & & 9 & 10 & & & \\
\hline Hollanda & & & & & & 61,9 & \\
\hline Yeni Zelanda & 28 & 18,6 & 35,8 & 41,8 & 37,5 & 31,5 & 32,9 \\
\hline Norveç & & & & & & 61,8 & \\
\hline Polonya & 14,3 & & & & & 16,8 & \\
\hline Portekiz & 60,8 & & & & & 42,1 & \\
\hline Rusya Federasyonu & 28,4 & & & & & 20,6 & \\
\hline Slovakya & 7,6 & & & & 11,5 & 11,2 & \\
\hline Slovenya & 20 & & & & 32,8 & 30,8 & \\
\hline Güney Afrika & 10,9 & 9,7 & 11,3 & 14,5 & 12,8 & 13,5 & \\
\hline İspanya & 73,9 & & & & 53,2 & 46,9 & \\
\hline İsveç & 64,8 & & & & 28,4 & 28 & \\
\hline İsviçre & 71,4 & & & & 64,7 & 61,9 & \\
\hline Tayvan & 16,4 & & 32,7 & 14,6 & 13 & 15,8 & \\
\hline Tacikistan & 5 & & 3,8 & 5,3 & 8,5 & 9,2 & \\
\hline Tayland & 11,1 & 13,8 & 24,3 & 22,4 & 37,1 & 28,5 & \\
\hline Türkiye & 4,3 & & & & 6,5 & 7,7 & \\
\hline Ukrayna & 34,4 & & & & 21,3 & 20,9 & \\
\hline Birleşik Krallık & 53,8 & & & & 60,8 & 62,6 & \\
\hline Amerika Birleşik Devletleri & 35,9 & 37 & 40,4 & 30,6 & 27,2 & 26,5 & \\
\hline Uruguay & 12,5 & 16,1 & 21,3 & 22,4 & 25,4 & 27,9 & \\
\hline Özbekistan & 61,1 & 39,5 & 0 & 0 & & & \\
\hline Vietnam & 0 & 0 & 0,7 & 10,8 & 9,5 & 8,4 & \\
\hline
\end{tabular}

Kaynak: ILO, ILOSTAT, >http://www.ilo.org/ilostat/faces/oracle/webcenter/portalapp/pagehierarchy/>, 11.05.2017.

İşsizlik sigortasından yararlanabilmek için kapsamda olmak yeterli olmamakta, başvuru koşullarını da sağlamak gerekmektedir. Türkiye'de 2016 yılına göre, isssizlerin yaklașı yarısı ișsizlik ödeneğine başvurmuștur. İşsizlik ödeneği devam edenlerin işsiz sayısına oranı ise 2016 yılı itibariyle sadece \%10,5'dur. (Şekil 3). 
Şekil: 3

Türkiye'de İşsizlik Ödeneğine Başvuranların İşsiz Sayısına Oranı (\%) ve İşsizlik Ödeneği Devam Edenlerin İşsiz Sayısına Oranı (\%), 2009-2016

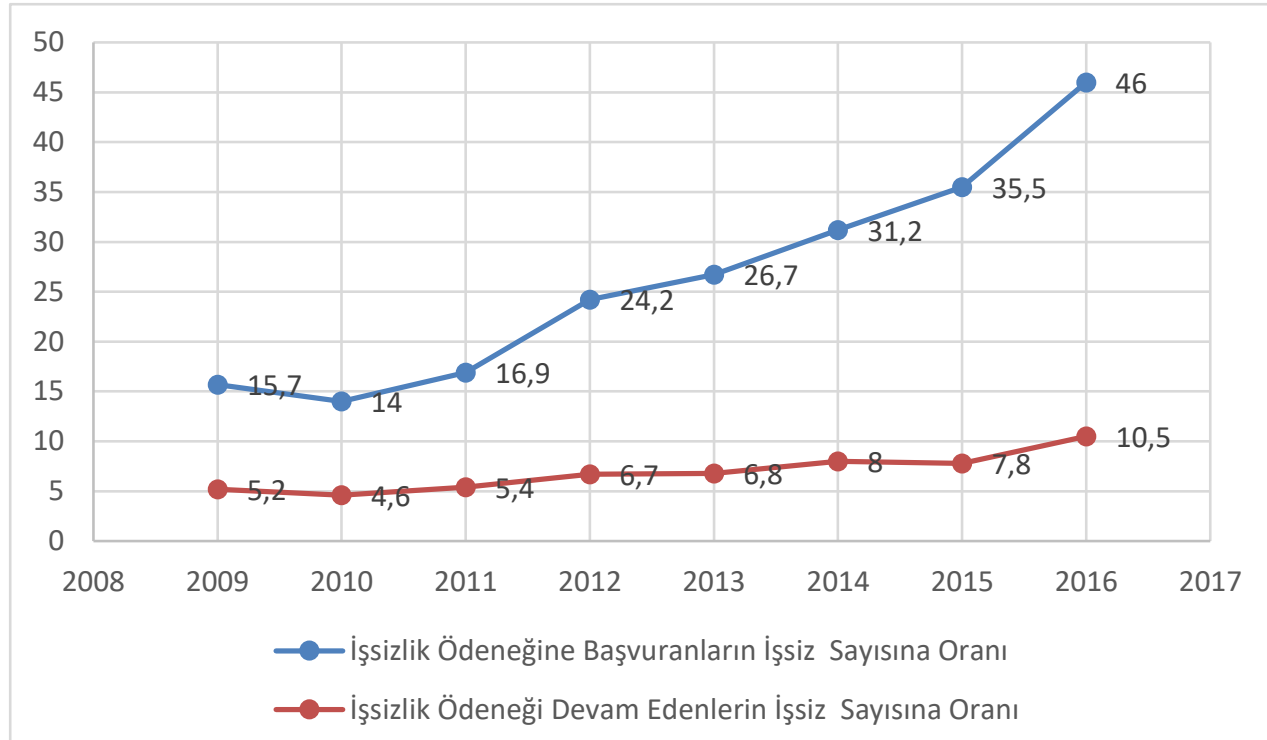

Kaynak: IŞKUR 2009-2016 İstatistik Ylllıkları ve TÜIK 2009-2016 Hane Halkı İşgücü Istatistikleri verilerinden yazarlar tarafindan hesaplanmıştır.

SGK verilerine göre 2015 yılında işten çıkış sayısı toplam, 16.156.845'dir, İşsizlik Sigortası Yasası'nda yer alan kendi istek ve kusuru dışında işini kaybedenlerin oranı ise \%28'dir (IŞSUR, 2016: 9). Üstelik söz konusu oranın içinde işsizlik sigortası prim ödeme şartını (son üç yılda 600 gün ve işten ayrılmadan önce kesintisiz 120 gün prim ödeme şartı) yerine getirmeyenler de bulunmaktadır. Diğer yandan Aralık 2015 yılı itibariyle gerekli prim ödeme şartını yerine getirip, işten ayrılan 961.069 işsizden 96.439 kişi işsizlik ödeneğine başvurmuş ve sadece 59.108 kişi işsizlik ödeneğine hak kazanabilmiştir (İŞKUR, 2016: 8) (Şekil 4). 
Şekil: 4

2015 Yılı İtibariyle İşsizlik Sigortası için Prim Ödeme Gün sayısını Dolduran Hak Kazanan ve İşten Ayrılan ve İşsizlik Sigortası Ödeneğini Hak Eden Sigortalı Sayıları

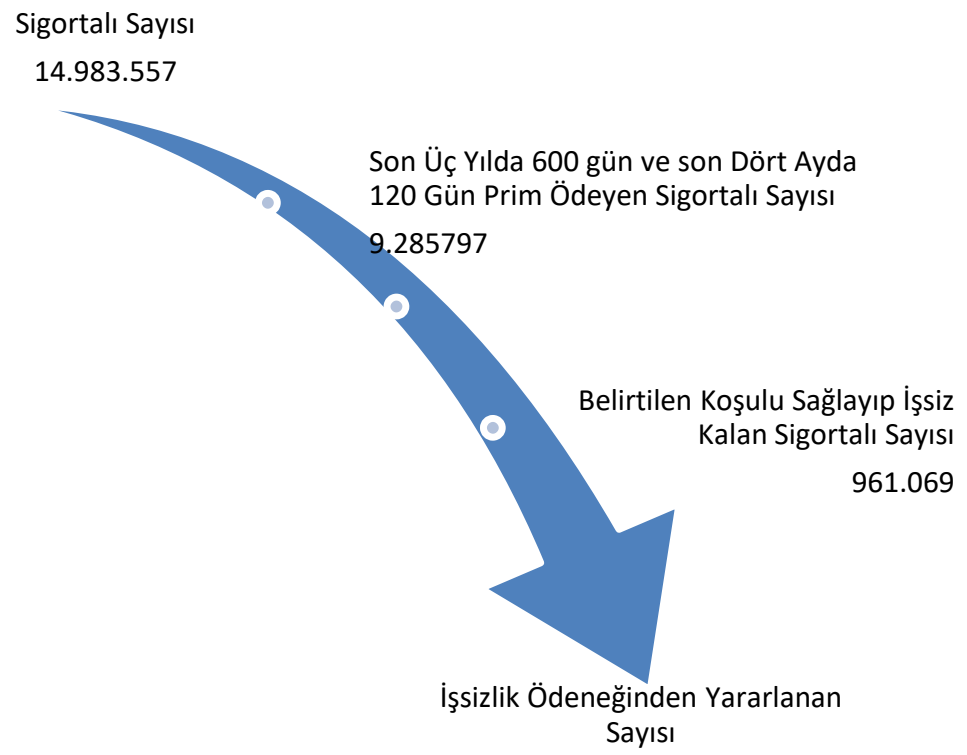

59.108

Kaynak: IŞKUR, 2016: 8.

\subsection{Sigortalılık Süresi ve Prim Ödeme Gün Sayısının Yüksekliği: Avrupa Ülke Örnekleri ile Karşılaştırma}

4447 sayılı Yasa'nın 51. maddesi uyarınca "sigortalı sayılanlardan.... hizmet akitlerinin sona ermesinden önceki son üç yıl içinde en az 600 gün sigortalı olarak çalışıp işsizlik sigortası primi ödemiş ve işten ayrılmadan önceki son 120 gün içinde prim ödeyerek sürekli çalışmış olmaları kaydıyla işsizlik ödeneği almaya hak kazanırlar.” İş sözleşmesin sona ermesinden önceki son 120 gün içinde, iş sözleşmesinin devam etmesi koşulu ile hastalık, ücretsiz izin disiplin cezası, gözaltına alınma, hükümlülükle sonuçlanmayan tutukluluk hali, kısmi istihdam, grev, lokavt, genel hayatı etkileyen olaylar, ekonomik kriz, doğal afetler nedeniyle işyerinde faaliyetin durdurulması veya işe ara verilmesi halinde, son 120 günün hesabında prim tahakkuk ettirilmemiş süreler kesinti sayılmamaktadır ${ }^{4}$. 
Kumaş, H. \& O. Karadeniz (2017), “Türkiye'de İşsizlik Sigortası Ödeneği'nden Yararlanan İşsiz Sayısının Düşük Olma Nedenleri: AB Ülkeleri İle Bir Karşılaştırmalı Bir Analiz”, Sosyoekonomi, Vol. 25(33), 195-220.

İlgili düzenlemeye göre işsizlik sigortası uygulamasından yararlanmak için yasanın zorunlu kıldığı gerekli prim ödeme koşullarını doldurmak oldukça güç gözükmektedir. Yarı zamanlı ve mevsimlik çalı̧̧anların son üç yılda 600 günü tamamlaması neredeyse olanaksızdır. Örneğin günde 3, ayda 60 saat çalışan bir yarı zamanlı çalışanın sigorta primi ay içindeki çalışma süresinin (saat), 4857 sayılı İş Yasası'ndaki (63. madde) günlük ortalama çalışma süresine (7,5 saat) bölünmesi ile bulunmaktadır. Örnekteki sigortalının çalışma gün sayıs1 da bir ay içinde 8 gün $(60 / 7,5=8$ gün) olarak Sosyal Güvenlik Kurumu'na bildirilecektir. Bu durumda sigortalının yıllık prim gün sayısı 96, üç yıllık ise 198 gün olacak ve işsizlik sigortasına hak kazanamayacaktır. Örneği verilen çalışan haftada 30, ayda ise 120 saat çalıştığında çalışmaları Sosyal Güvenlik Kurumu'na $16(120 / 7,5=16)$ gün olarak bildirilecek ve üç yıllık sigortalı çalı̧̧ma süresi 576 gün olacaktır. Yasa gereği $i^{5}$ yarı zamanlı çalışanlardan işsizlik sigortası primi kesilmektedir. Ancak örnekten de görüleceği üzere yarı zamanlı çalı̧̧anlar işsizlik sigortasından yararlanamamaktadır. Düzenleme gelir seviyesi düşük yarı zamanlı çalışanların sosyal sigorta edimlerinden yararlanmasını güçleştirmektedir (Karadeniz, 2011/a).

İşsizlik sigortasının primlerle finanse edildiği ülkelerde prim ödeme süresi ne kadar kısa ve prim miktarı ne kadar düşük ise işsizlik sigortasından yararlanmak o ölçüde kolaylaşmaktadır.

MISSOC 2016 verilerinden yararlanılarak 24 Avrupa ülkesi için işsizlik sigortası prim ödeme gün sayısı ve/veya sigortalılık süresi ile ilgili bir inceleme yapılmış, kriz ve sonrası etkilerini görebilmek için 2009 ve 2016 yılları karşılaştırılmıştır. İnceleme sonunda, Bulgaristan, İsviçre, Almanya, Estonya, Yunanistan, İspanya, Fransa, Avusturya, Polonya, Romanya, Lüksemburg ve İrlanda'da olmak üzere on iki ülkede işsizlik sigortası ödeneği alabilmek için prim ödeme gün sayısı ve/veya sigortalılık süresinde herhangi bir değişiklik yapılmadığı, on iki ülkede ise koşulların değiştiği görülmüştür (Ek Tablo 1).

2009 ve 2016 yılları için işsizlik sigortasının bağlanmasına ilişkin yapılan değişikler, sigortalılık süresinin uzatılması veya kısaltılması, belirli bir süre içinde toplam çalışma saatin belirlenmesi, ücretli veya bağımsız olarak çalışma zorunluluğunun getirilmesi biçimindedir.

Örneğin; Belçika'da yaşa bağlı olmakla birlikte, 2009 yılında işsizlikten önceki son 36 ayda 264 işgünü ve son 18 ayda 312 işgünü prim ödeme/sigortalılık koşulu, 2016 yılında son 42 ayda 264 işgünü ve son 21 ayda 312 işgünü biçiminde değiştirilerek, işsiz kişiye koşullarda göreceli de olsa esneklik sağlanmıştır. Belçika'da sigortalılık süresinin

5 13/2/2011 tarihli ve 6111 sayılı Yasa'nın 68 inci maddesiyle, bu fikrada yer alan "dayalı olarak çalışan sigortalılarl” ibaresinden sonra gelmek üzere", 4857 sayll yasaya göre kasmi süreli iş sözleşmesi ile çalışanlardan 5510 sayılı Yasa'nın 52 nci maddesinin birinci fikrası kapsaminda işsizlik sigortası primi ödeyen isteğe bağll sigortalılar ile aynı yasanın ek 6 ncı maddesi kapsamındaki sigortalıları" ibaresi eklenmiş ve metne işlenmiştir. 
esnekleşmesinin nedenlerinden biri, işsizlik oranlarının daha inatçı bir yapı sergilemesi olabilir. Örneğin, 2009 yilında (\%7,9) (European Commission, 2014: 262) ve 2016/7. Ayında (8,0) (Eurostat, E.T. 13.03.2016) işsizlik oranları neredeyse aynıdır. Danimarka'da Temel İşsizlik Sigortası Ödeneğinin bağlanması için 2009 yılında son 3 yılda en az 52 hafta tam zamanlı çalışma zorunluluğu aranırken, 2016 yılında aynı süre için 1924 saat çalışma zorunluluğu getirilmiştir. Danimarka'da haftalık çalışma sürelerinin kısaltılmasının nedeni, istihdam oranın yüksekliği (2015 y1lı \%76,5, Eurostat, 13.03.2016) çalışma sürelerinin esnekleştirilmesinin ve yarı zamanlı çalışma uygulamalarının yoğun biçimde yaşandığ ülkelerden birisi olması ile açıklanabilir (European Commission, 2015: 96-295). Danimarka örneğinde olduğu gibi çalışma sürelerinin esnekleştirilmesi işsizlik sigortasının bağlanma koşullarını değiştirebilecektir. AB ülkeleri içinde yarı zamanlı çalışmanın en fazla olduğu (toplam istihdamın \%50,4'ü - European Commission, 2015: 417) ve esnek çalışma saatlerinin en yaygın olarak uygulandığı diğer bir ülke olan Hollanda da işsizlik sigortası ödeneğinden yararlanmada hafta koşulu yerine, saat koşulu getirilmiştir (işsizlikten önceki beş takvim yılının dördünde 52 hafta yerine, 208 saat istihdam edilme koşulu). Bununla birlikte işsizlik oranının en yüksek olduğu İspanya (2016/7.ay: \%19,5) ve Yunanistan'da (2016 7.ay \%23,3) (Eurostat, E.T. 13.03.2016) işsizlik sigortası koşullarında bir değişiklik olmamıştır. 
Şekil: 5

Ülke Örnekleri ile İşsizlik Sigortasından Yararlanabilmek İçin Ödenmesi Gerekli Asgari Prim Ödeme Gün Sayısının İşsiz Kalmadan Önceki Sigortalılık Süresine Oranı (\%) 2015

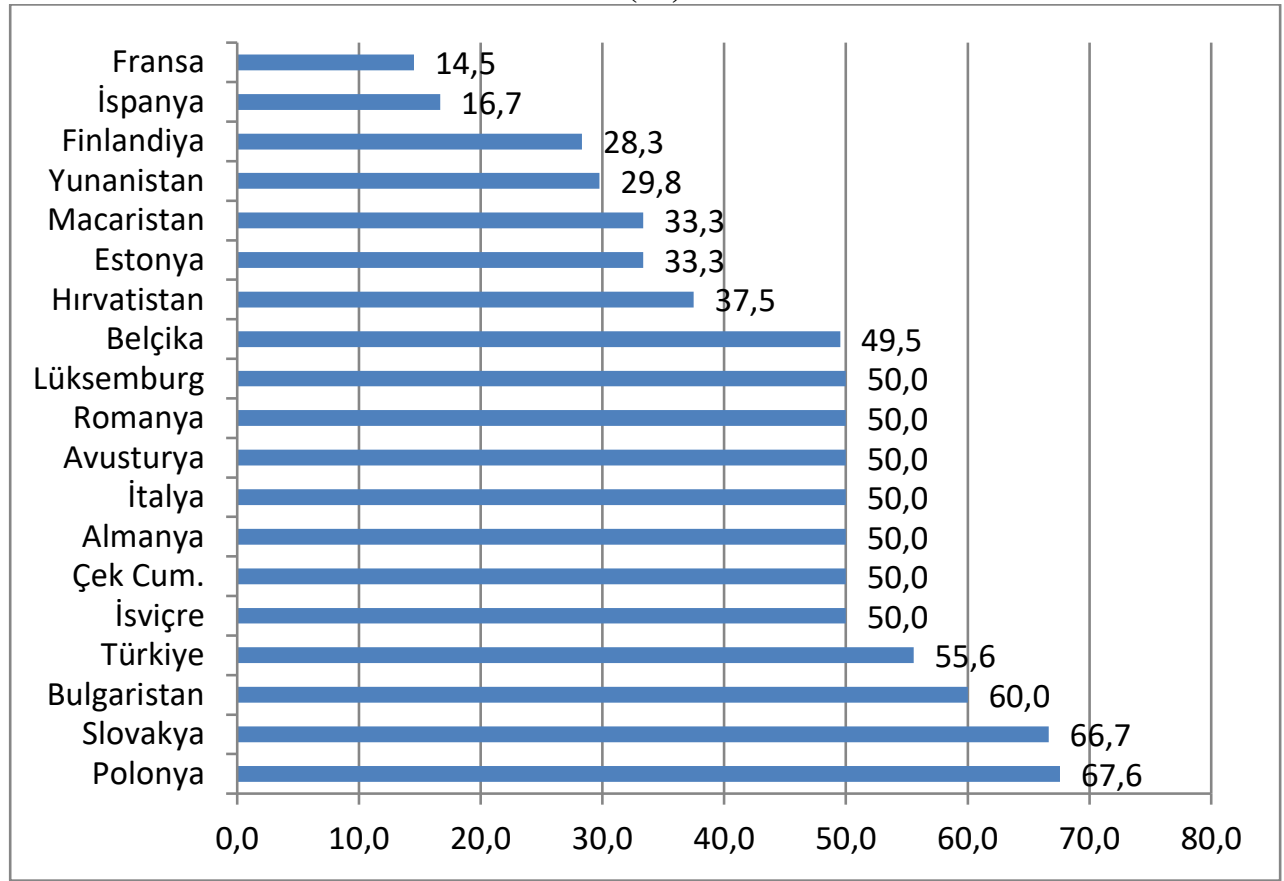

Kaynak: MISSOC Comparative Tables Database 2015'den yararlanılarak oluşturulmuştur.

Türkiye'de ise işsizlik ödeneğinden yararlanabilmek için işsiz kalmadan önce son üç yıl içinde (1080 gün) 600 gün işsizlik sigortası primi ödemek gereklidir. Diğer bir ifade ile son üç yılın \%55'inde $(600 / 1080=0,55)$ prim ödeme yükümlülüğünün yerine getirilmesi gerekmektedir. Söz konusu oran Fransa'da \%15, İspanya'da \%17 iken, Slovakya'da \%75, Bulgaristan'da \%60, Belçika'da \%58, İsviçre, Almanya ve İtalya'da \%50'dir. Ayrıca, Türkiye sigortalılık süresi içinde prim ödeme gün sayının en yüksek olduğu ülkelerden birisidir. Bu durum, işsizlik sigortasından yararlanmak için gerekli prim ödeme gün sayısının doldurulmasını zorlaştırmaktadır (Şekil 5). Bu bağlamda, ülkelerin işsizlik sigortası kapsamını genişletme ve ödenek alma süresini uzatmaya yönelik çabalarını geliştirirken, kapsam ve miktarın artırılmasında işsizlik süresini uzatan teşvikleri de dikkate alması gerekmektedir (OECD, 2009: 3).

\section{4. İşgücü Piyasasından Kaynaklanan Sorunlar}

İşgücü piyasasında özellikle düşük katma değer yaratan, emek yoğun işletmelerde işverenlerin işgücü maliyetini azaltabilmek için işçilerini iş sözleşmeni istifa etmiş gibi İ̧SUR'a bildirmesi sık rastlanan bir olgudur. Ancak ilgili yasaya göre işsizin işsizlik 
sigortasından yararlanabilmesi için kendi isteği ve kusuru dışında işsiz kalması gerekmektedir.

TÜİK İşgücü İstatistiklerine göre (2016), işten çıkartıldı̆̆ı için işsiz kalanların oranı sadece \%11,4'dür (Şekil 6). İşsizlerin yaklaşı1k \%5'ini ise ilk kez iş arayanlar oluşturmaktadır ki, söz konusu grup zaten işsizlik sigortası primi ödemediği için kapsam dışı kalmaktadır. Kendi isteği ile işinden ayrılanlar (\%19,2), işyerini kapatanlar veya iflas edenler $(\% 5,7)$, emeklilerin de $(\% 2,8)$ işsizlik sigortasından yararlanmaları yasal olarak mümkün değildir. Ayrıca, geçici çalışanların kayıtlı çalıştıkları varsayımı altında bile son 3 yıl içinde 600 gün işsizlik sigortası primi ödeme şartını yerine getirmeleri mümkün gözükmemektedir.

\section{Şekil: 6 \\ Türkiye’de İşsizlik Nedenleri (2016 Yılı) (\%)}

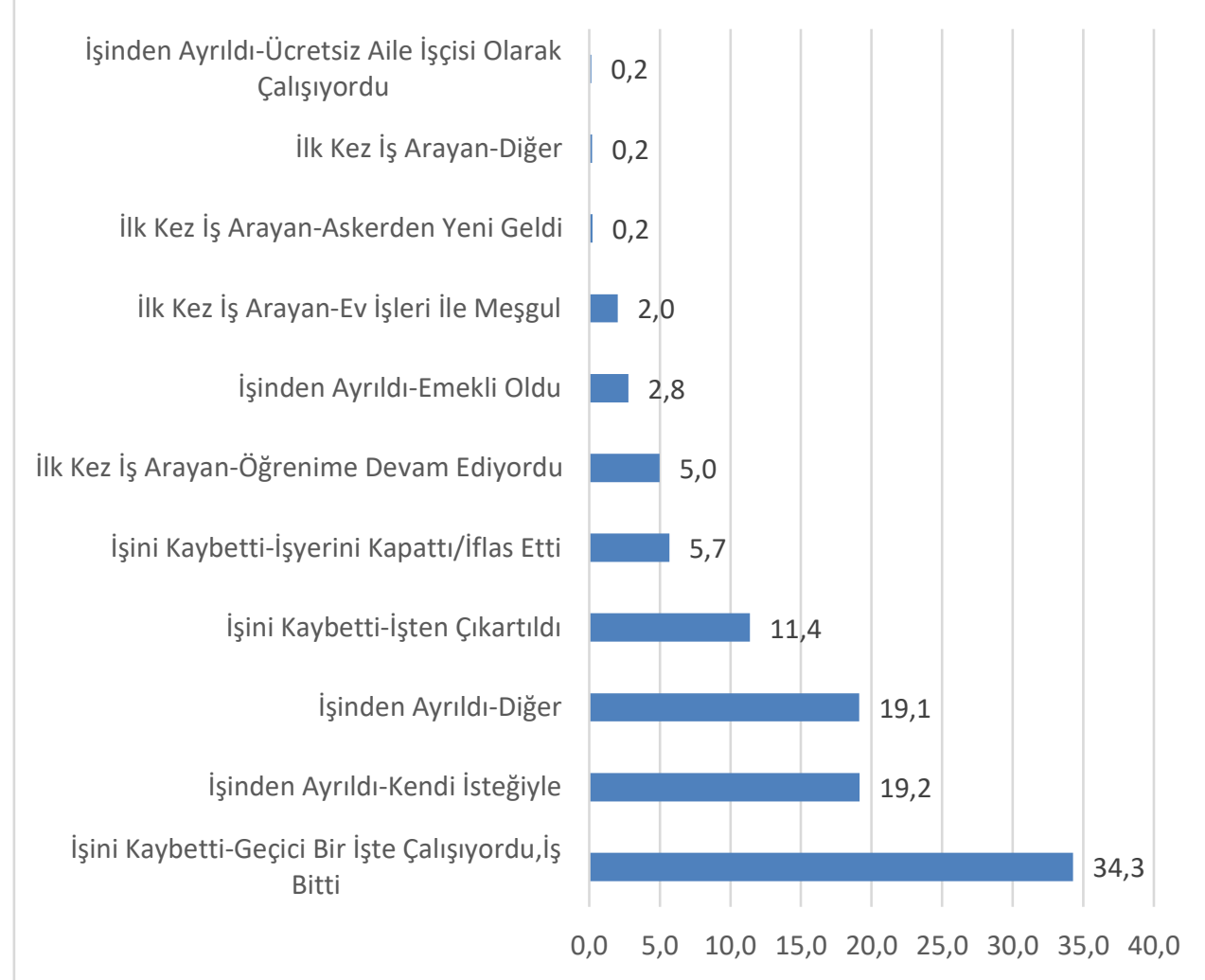

Kaynak: TÜIK, İşgücü İstatistikleri 2016'den oluşturulmuştur, <http://tuik.gov.tr/PreTablo.do?alt_id=1007>, 05.04.2017.

İşçilerin hak ettikleri halde işsizlik sigortası ödeneği alamamasının bir diğer nedeni işverenlerin işten çıkardıkları işçilere kıdem tazminatı vermemek için işten ayrılma 
nedenlerini SGK'ya istifa olarak bildirmesi olabilir. Karadeniz (2011/b) tarafından ÇSGB işten çıkış istatistikleri üzerinden yapılan bir çalışmada da, işten ayrılan işçilerin neredeyse yarısının işten ayrılış nedeninin istifa olarak bildirildiği, 2008 yılı itibariyle iş ilişkisinin sadece \%22'sinin kıdem tazminatı alabilecek şekilde sona erdirildiği sonuçlarına ulaşılmıştır.

\section{Sonuç ve Öneriler}

Türkiye'de işsizlik sigortası yaklaşık 50 yıl tartışıldıktan sonra 2000 yılında yürürlüğe girmiştir. Ancak uzun yılların beklentisine rağmen cılız bir sosyal sigorta programı ortaya çıkmıştır. Türkiye'deki işsizlik sigortası programı, diğer ülkeler ile karşılaştırıldığında kapsam itibariyle dar, yararlanma koşulları açısından zor bir sosyal koruma programını içermektedir.

Ülkemizde işsizlik sigortası çalışan olarak nitelenen birçok grubu kapsamamaktadır. Tarımda geçici çalışanlar, ücretsiz aile işçileri de işsizlik sigortası kapsamına girememektedir. Ayrıca, 5510 sayılı yasa kapsamında iş sözleşmesine göre çalışmasalar dahi, benzer biçimde sosyal sigorta güvencesi kapsamına alınan, yazarlar, sanatçılar, sendika ve konfederasyonların yönetim kurullarına seçilenler, genelev kadınları, çiftçi malları koruma bekçileri, kısmen sigortalı sayılan çıraklar, stajyerler, ceza ve tutukevlerinde çalıştırılan işçiler, Türkiye'deki işverenler tarafından ikili sosyal güvenlik sözleşmesi imzalanan ülkelere gönderilen işçiler, 657 sayılı Yasa'nın 4. maddesinin c fikrasına göre çalıştırılan geçici personel gibi çalışma koşulları ağır ve sosyo-ekonomik açıdan kırılgan kesimler de işsizlik sigortasının kapsamı dışında kalmaktadır. Yarı zamanlı çalışanlar, mevsimlik çalışanlar ise işsizlik sigortası primi ödemekle birlikte, son 3 yıl içinde 600 gün prim ödeme şartını dolduramadıkları için işsizlik sigortasından yararlanamamaktadırlar.

Kendi hesabına çalışanlar için getirilen Esnaf ve Ahilik Sandığı Fonu ile işsizlik sigortası benzeri bir uygulamanın, esnaf ve sanatkârlar ile şirket ortaklarına yaygınlaştırılması olumludur. Ancak söz konusu Sandık 2018 yılında prim toplamaya başlayacaktır.

İşsizlik sigortasından yararlanan sayısının düşük olmasına neden olan bir diğer koşul, kayıt dışı çalışmadır. Kayıt dışı çalışanlar, hiçbir biçimde işsizlik sigortasına başvuramamaktadır. Türkiye'de işsizlik tehlikesinin en yüksek olduğu gruplardan biri olan gençlerinde işsizlik sigortasından yararlanmaları oldukça güçtür. Çünkü mevcut sistem işgücü piyasasına yeni giren ve daha önce işsizlik sigortası primi ödememiş kişileri kapsamamaktadır. Ayrıca, ülkemizde bazı Avrupa ülkelerinde olduğu gibi işsizlik sigortasından yararlanabilmek için gerekli prim ödeme gün sayısını yerine getiremeyen ve işgücü piyasasına yeni girmiş işsizler veya genç işsizler için vergilerle finanse edilen işsizlik yardımı da bulunmamaktadır.

Türkiye için işsizlik sigortasından yararlanma oranının düşüklüğünde dört ana temel nedenin etkili olduğu ifade edilebilir: 
Kumaş, H. \& O. Karadeniz (2017), “Türkiye'de İşsizlik Sigortası Ödeneği’nden Yararlanan İşsiz Sayısının

Düşük Olma Nedenleri: AB Ülkeleri İle Bir Karşılaştırmalı Bir Analiz”, Sosyoekonomi, Vol. 25(33), 195-220.

- İşsizlik sigortasının kapsamının darlığı ve sistemin mevcut istihdam yapısını ve sektörel dağılımı dikkate almadan hazırlanmış olması,

- İşsizlerin büyük çoğunluğunun işsizlik sigortasından yararlanamayacak şekilde işsiz kalması (ilk defa iş arayanlar, kendi istekleriyle işsiz kalanlar vb.),

- İşsizlerin geçmiş yıllarda kayıt dışı çalışmaları nedeniyle işsizlik sigortasından yararlanmak için gerekli prim ödeme gün sayısının dolduramaması,

- İşverenlerin çoğunlukla kıdem tazminatı ödememek için işçilerin işten ayrılışlarını istifa gibi göstermeleri.

Yukarıdaki tespitler 1şığı altında Türkiye'de işsizlik tehlikesine karşı koruma kapsamını genişletmek, edimlerden yararlanma koşullarını kolaylaştırmak için:

- İşsizlik sigortasının kapsamı dışında kalanlar ya da gerekli prim ödeme gün sayısını dolduramayan çalışanlar için vergilerle finanse edilen bir işsizlik yardımı uygulamaya konulmalıdır. İşsizin söz konusu yardımlardan yararlanabilmesi için $\mathrm{AB}$ ülkelerinde olduğu gibi mesleki eğitim kurslarına ve staj programlarına katılması zorunlu tutulabilir,

- İşs sözleşmesine istinaden çalışmasalar dahi, yazarlar, sanatçılar, çiftçi malları koruma bekçileri, genelev kadınları, sendika ve konfederasyonların yönetim kurullarına seçilenler, Türkiye'deki işverenler tarafından ikili sosyal güvenlik sözleşmesi imzalamadığımız ülkelere gönderilen işçiler, kamu kurumlarında ders saat ücreti karşılı̆̆ görevlendirilenler işsizlik sigortası kapsamına alınmalıdır. 657 sayılı Devlet Memurları Yasası'nın 4. maddesinin c fikrası kaldırılmalı, bu şekilde çalıştırılanlar kadroya alınmalı ve daimi işçi statüsünde çalıştırılarak işsizlik sigortası hükümlerinden yararlandırılmalıdır.

- İşsizlik sigortasından yararlanmak için gerekli prim ödeme koşulu yarı zamanlı ve mevsimlik çalışanlar açısından yeniden düzenlenmeli ve doğum, askerlik nedeniyle prim ödenemeyen sürelerin prim ödenmiş gibi dikkate alınması ya da sonradan borçlanması sağlanmalıdır.

- İşverenlerin işten ayrılışları istifa gibi göstermesi önlenmelidir.

Sonuç olarak, işsizlik sigortasının kıdem tazminatı uygulaması ile değerlendirilerek yeniden düzenlenmesi gerekmektedir. Gelecekteki çalışmaların, işsizlik sigortasını miktarı, süresi, prim ve edim ilişkisi bağlamında ülke örnekleri ile karşılaştırılarak daha detaylı ve ilgili diğer yasaları da kapsayacak biçimde yapılması, Türkiye işgücü piyasasının toplumsal refahı artıracak biçimde düzenlemesine katkı sağlayabilir.

\section{Kaynaklar}

Andaç, F. (2010), İssizlik Sigortası, 2. Baskı, Ankara: TÜHİS Yayınları: 66.

Başterzi, S. (1996), İssizlik Sigortası, Ankara: Ankara Üniversitesi Hukuk Fakültesi Yayınları No: 509.

Dilik, S. (2000), “Türkiye'de İşsizlik Sigortasının Kuruluşu Yönünden 25.08.1999 Tarihli 4447 Saylı Kanunun Eleştirisi”, Gazi Üniversitesi İ̈BF Dergisi, 2(1), 1-16. 
DPT, Uzun Vadeli Strateji ve Sekizinci Beş Yıllık Kalkınma Planı 2001-2005, $<$ http://www.bilgitoplumu.gov.tr/wpcontent/uploads/2015/01/Sekizinci_Kalkinma_Plani.pdf>, 03.01.2016.

European Commission (2015), Employment and Social Developments in Europe 2015, Brussels: European Commission Directorate-General for Employment, Social Affairs and Inclusion.

Eurostat, Statistics and Opinion Polls, $<$ http://ec.europa.eu/eurostat/tgm/table.do?tab=table\&init=1\&language $=$ en \&pcode $=\mathrm{t} 202$ 0_10\&plugin=1>, 13.03.2016.

Güzel, A. \& A.R. Okur \& N. Caniklioğlu (2016), Sosyal Güvenlik Hukuku, Beta, 16. Bası İstanbul.

ILO (2009), "Social Security for all: Investing in Social Justice and Economic Development", Social Security Policy Briefings, Paper No. 7, Geneva: ILO.

ILO (2012), ILO Newsroom, Unemployment Insurance More Than 70 Per Cent of Workers Lack Unemployment Protection, <http://www.ilo.org/global/about-theilo/newsroom/comment-analysis/WCMS_193133/lang--en/index.htm>, 22.08.2015.

ILO (2014), World Social Protection Report 2014/15 Building Economic Recovery, Inclusive Development and Social Justice 2014/15", Geneva: ILO.

ILO, Social Protection, Data \& Indicators, <http://www.socialprotection.org/gimi/gess/RessourceDownload.action?ressource.ressourceId=37697>, 18.07.2015.

İŞKUR (2009-2014), Istatistik Yıllıklarl, <http://www.iskur.gov.tr/trtr/kurumsalbilgi/istatistikler.aspx\#dltop>, 11.05.2017.

İŞKUR (2016) İssizlik Sigortası Fonu, 2015 Yllı Aktueryal Değerlendirme Raporu, <file:///C:/Users/Oguz/Downloads/2015\%20AKT\%C3\%9CERYAL\%20B\%C4\%B0LAN \%C3\%87O\%20DENET\%C4\%B0M\%20RAPORU.pdf>, 06.03.2017.

İSKUR, İssizlik Sigortası, <http://www.iskur.gov.tr/tr-tr/isarayan/issizliksigortasi.aspx>, 17.05.2016.

Karadeniz, O. (2011/a), “Türkiye'de Atipik Çalışan Kadınlar ve Yaygın Sosyal Güvencesizlik", Çalışma ve Toplum, 29(2), 83-127.

Karadeniz, O. (2011/b), “Türkiye'de Kıdem Tazminatı Uygulamasının Kapsam ve Yararlanma Koşulu Açısından Değerlendirilmesi: İşçilerin Ne Kadarı Kıdem Tazminatına Hak Kazanıyor ya da Alabiliyor?", (Eds. K. Orhan \& H. Kumaş), Kıdem Tazminatı Uygulamada Yaşanan Sorunlar ve Çözüm Yolları, Ankara: Gazi, 109-123.

Lentz, R. (2008), Optimal Unemployment Insurance in an Estimated Job Search Model with Savings, WI 53706-1393, USA.

MISSOC (2009), Comparative Tables Database 2009, <http://www.missoc.org/MISSOC/INFORMATIONBASE/COMPARATIVETABLES/ MISSOCDATABASE/comparativeTablesSearchResult.jsp>, 08.07.2013.

MISSOC (2012), Comparative Tables Database 2012, <http://missoc.org/MISSOC/INFORMATIONBASE/COMPARATIVETABLES/MISSO CDATABASE/comparativeTableSearch.jsp>, 08.07.2013.

MISSOC (2015), Comparative Tables Database 2015, <http://missoc.org/MISSOC/INFORMATIONBASE/COMPARATIVETABLES/MISSO CDATABASE/comparativeTableSearch.jsp>, 01.07.2015. 
MISSOC (2016), Comparative Tables Database 2016,

<http://www.missoc.org/MISSOC/INFORMATIONBASE/COMPARATIVETABLES/

MISSOCDATABASE/comparativeTableSearch.jsp>, 10.03.2017.

OECD (2009), OECD Employment Outlook: Tackling the Jobs Crisis, Paris.

T.C. Kalkınma Bakanlığı (2013), Onuncu Beş Yıllık Kalkınma Planı 2014-2014, Ankara, $<$ http://www.kalkinma.gov.tr/Lists/Kalknma\%20Planlar/Attachments/12/Onuncu\%20Kal k\%C4\%B1nma\%20Plan\%C4\%B1.pdf>, 12.12.2016.

The World Bank (2012), World Development Report 2013: Jobs, Washington DC.

TÜİK (2009 - 2016), Isşü̈ü İstatistikleri, <http://tuik.gov.tr/PreTablo.do?alt_id=1007>, 05.04.2017. 
Kumaş, H. \& O. Karadeniz (2017), “Türkiye'de İşsizlik Sigortası Ödeneği’nden Yararlanan İşsiz Sayısının

Düşük Olma Nedenleri: AB Ülkeleri İle Bir Karşılaştırmalı Bir Analiz”, Sosyoekonomi, Vol. 25(33), 195-220.

\section{Ek Tablo: 1}

\section{İşsizlik Sigortasından Yararlanma Koşulları: Avrupa Ülke Örnekleri*}

\begin{tabular}{|c|c|c|}
\hline ÜLKELER & DÖNEM & GEREKLİ PRİM ÖDEME GÜN SAYISI / SİGORTALILIK SÜRESİ \\
\hline \multirow{2}{*}{ Belçika } & 2009 & $\begin{array}{l}\text { Son } 36 \text { ayda } 624 \text { işgünü ve son } 18 \text { ayda } 312 \text { işgünü arasında olacak biçimde sigortalının yaşına göre katkı dönemleri } \\
\text { değişiklik göstermektedir. }\end{array}$ \\
\hline & 2016 & $\begin{array}{l}\text { Son } 42 \text { ay içinde } 624 \text { iş günü ve son } 21 \text { ay içinde } 312 \text { iş günü arasında sigortalının yaşına göre katkı dönemleri değişiklik } \\
\text { göstermektedir. }\end{array}$ \\
\hline \multirow{2}{*}{ Bulgaristan } & 2009 & İşsizlikten önceki son 15 ayda en az 9 ay prim ödemek gerekmektedir. (tüm tehlikelere karşı sigorta primi ödenmelidir) \\
\hline & 2016 & Koşullarda değişiklik olmamıştır. \\
\hline \multirow[t]{2}{*}{ İsviçre } & 2009 & $\begin{array}{l}\text { İşsizlikten önceki } 2 \text { yıl içinde } 12 \text { ay katkı yapılmalıdır. } \\
\text { Belirli kişiler için prim ödeme süresi koşulu yoktur. } \\
\text { İşsizlik sigortası yardımı olmadan bağımsı çalışmaya başlayanlar veya çocuk yetiştiren kişiler için daha uzun başvuru } \\
\text { dönemleri koşulu vardır. }\end{array}$ \\
\hline & 2016 & Koşullarda değişiklik olmamıştır. \\
\hline \multirow{2}{*}{$\begin{array}{l}\text { Çek } \\
\text { Cumhuriyeti }\end{array}$} & 2009 & $\begin{array}{l}\text { İstihdamda ya da diğer çalışma faaliyetleri ile geçen son } 3 \text { yıl içinde } 12 \text { ay temel emeklilik sigortası katkısı ödenmelidir. } \\
12 \text { aylık sigortalılık süresi, istihdam süresi yerine geçen (çocuk bakımı vb. gibi) sürelerle de tamamlanabilir. }\end{array}$ \\
\hline & 2016 & $\begin{array}{l}\text { İstihdamda veya diğer çalışma faaliyetlerinde geçen son } 2 \text { yıl içinde } 12 \text { ay temel emeklilik sigortası katkısı ödenmelidir. } \\
12 \text { aylık sigortalılık süresi, istihdam süresi yerine geçen (çocuk bakımı vb. gibi) sürelerle de tamamlanabilir. }\end{array}$ \\
\hline \multirow[b]{2}{*}{ Danimarka } & 2009 & $\begin{array}{l}\text { Temel ödenek için; son } 3 \text { yıllık sürede en az } 52 \text { hafta tam zamanlı çalışma süresi ile çalışmak gerekmektedir. } \\
\text { Sadece istihdam halindeki sigortalılık hesaba katılır. } \\
\text { Kazanca bağlı fonda en az } 1 \text { yıllık sigortalılık gerekmektedir. }\end{array}$ \\
\hline & 2016 & $\begin{array}{l}\text { Temel ödenek için: } \\
\text { Son } 3 \text { yıl içinde 1,924 saat (bir yıl içinde tam zamanlı istihdama karşılık gelen süre) çalışmak gereklidir. } \\
\text { Sadece istihdam halindeki sigortalılık hesaba katılır. } \\
\text { Kazanca bağlı fonda en az bir yıllık üyelik gereklidir. }\end{array}$ \\
\hline \multirow{2}{*}{ Almanya } & 2009 & İşsiz bireyin işsizlikten önceki 2 yıl içinde en az 12 ay zorunlu sigortalı olması gerekmektedir. \\
\hline & 2016 & Koşullarda değişiklik olmamıştır. \\
\hline \multirow{2}{*}{ Estonya } & 2009 & İşsizlik kaydından önceki 36 ay içinde 12 ayın sigortalı olarak (istihdam kaydının girilmiş olması) geçmesi gerekmektedir. \\
\hline & 2016 & Koşullarda değişiklik yoktur. \\
\hline \multirow[t]{2}{*}{ Yunanistan } & 2009 & $\begin{array}{l}\text { İş kaybından önceki } 14 \text { ay boyunca en az } 125 \text { gün veya } 2 \text { yil boyunca en az } 200 \text { gün prim ödemek gerekmektedir. Referans } \\
\text { dönemlerinde son iki ay hariç tutulmuştur. } \\
\text { İlk kez başvuranlar için son } 2 \text { yıl boyunca her çalışma yılı için ek } 80 \text { günlük süre gerekmektedir. } \\
01.01 .2014 \text { tarihinden bugüne son } 4 \text { takvim yılında } 400 \text { gün işsizlik sigortası alanlar işsizlik sigortasından yararlanamaz } \\
\text { ancak, } 400 \text { günden daha az yararlananlara işsizlik sigortası ödenmektedir. }\end{array}$ \\
\hline & 2016 & Koşullarda değişiklik olmamıştır. \\
\hline \multirow{2}{*}{ İspanya } & 2009 & İşsiz kalmadan önceki 6 yıl içinde en az 360 gün prim ödemek/katk1 yapmak gerekmektedir. \\
\hline & 2016 & Koşullarda değişiklik olmamıştır. \\
\hline \multirow[t]{2}{*}{ Fransa } & 2009 & $\begin{array}{l}\text { İşsizlikten önceki } 28 \text { ayda en az } 4 \text { ay (122 gün) prim ödemek gerekmektedir. (50 yaş ve üzerindeki sigortalılarda } 28 \text { ay } 36 \\
\text { ay olarak uygulanmaktadır) }\end{array}$ \\
\hline & 2016 & Koşullarda değişiklik olmamıştır. \\
\hline \multirow[b]{2}{*}{ İzlanda } & 2009 & $\begin{array}{l}\text { En yüksek yardımdan yararlanabilmek için İzlanda piyasasında ardışı } 12 \text { ay süreyle çalışmak gereklidir. En az miktarda } \\
\text { ödenek alabilmek için son } 12 \text { ayda } 3 \text { ay çalışmak gerekmektedir. } \\
\text { Yarı zamanlı çalışanların primleri orantılı olarak azaltılır. Ek olarak bağımsız çalışanlar, istihdamdan önceki } 1 \text { yıl içinde } \\
\text { sosyal güvenlik primi ve en az } 3 \text { yıl gelir vergisi ödemelidir. } \\
\text { İşsizin dönem başında } 3 \text { gün ardışı biçimde işsiz olarak kayıtlı olması gerekmektedir. }\end{array}$ \\
\hline & 2016 & $\begin{array}{l}\text { Sigorta miktarı en yüksek ve en düşük düzeyde belirlenmiştir. En yüksek yardımdan yararlanabilmek için İzlanda } \\
\text { piyasasında ardışı } 12 \text { ay süreyle çalışmak; en az miktarda ödeme alabilmek için son } 12 \text { ayda } 3 \text { ay çalışmak gerekmektedir. } \\
\text { Yarı zamanlı çalışmada oransal ödemeler yapılır. } \\
\text { Serbest/kendi hesabına çalışanlar işşiz kalmadan önce en yüksek ödenek için son } 1 \text { yıl boyunca, en az ödenek için en az } 3 \text { ay } \\
\text { boyunca sosyal güvenlik katkısı ödemelidir. } \\
\text { İşsizin dönem başında } 3 \text { gün ardışı biçimde işsiz olarak kayıtlı olması gerekir. }\end{array}$ \\
\hline \multirow[b]{2}{*}{ İtalya } & 2009 & $\begin{array}{l}\text { Normal isssizlik ödeneği için: } \\
\text { Son } 2 \text { yıl boyunca } 52 \text { hafta katk1 yapmak veya } 2 \text { yıl sigortalılık süresi gerekmektedir. } \\
\text { Özel işsizlik ödeneği için; İnşaat sektöründe son } 2 \text { yıl boyunca } 43 \text { hafta katk1 yapmak veya } 10 \text { ay sigortalı olmak } \\
\text { gerekmektedir. }\end{array}$ \\
\hline & 2016 & $\begin{array}{l}\text { İstihdam Sosyal Ödeneği: } \\
\text { İşsizin en son işsizlik ödeneği aldıktan sonra en az } 2 \text { yıl sigorta katkısı yapmış olması gerekmektedir. } \\
\text { En Az İstihdam Sosyal Ödeneği: } \\
\text { İşten çıarılmadan önceki son } 12 \text { ay boyunca en az } 13 \text { haftalık ( } 3 \text { ay) sigorta katkısı gerekmektedir. } \\
\text { ATİPIK Çalışanlar; işten çıkarılmadan önceki yıl içinde artı } 1 \text { aylık ve takvim yılı içinde } 3 \text { aylık katkının ödenmesi } \\
\text { gerekmektedir. } \\
\text { Yeni Sosyal Sigorta Uygulamalarına göre, tüm işsizler için işsizlikten önceki dört yıl boyunca en az } 13 \text { haftalık çalışma } \\
\text { sigortası ve işten çıkarılmadan önceki son } 12 \text { ay boyunca en az otuz gün çalışma sigortası ödenmelidir. } \\
\text { İşsizliğin sosyal kontrolü; hala işsiz olan } 55 \text { yaşın üstünde yararlanıcılar, İşYasası ile sağlanan önlemler çerçevesinde } \\
\text { yararlanabilmektedir. } \\
\text { Atipik istihdam sözleşmesi ile çalışanlar işsizlik sigortasında yararlanabilmektedir. } \\
\text { İnşaat sektörü hariç tüm çalışanlara hareketlilik yardımı yapılmaktadır. }\end{array}$ \\
\hline \multirow{2}{*}{ Macaristan } & 2009 & İşsiz kalmadan önceki 4 yılda 365 gün sigortalı olmak \\
\hline & 2016 & Son 3 yıl boyunca en az 360 gün sigortalı olmak. \\
\hline
\end{tabular}


Kumaş, H. \& O. Karadeniz (2017), “Türkiye'de İşsizlik Sigortası Ödeneği’nden Yararlanan İşsiz Sayısının

Düşük Olma Nedenleri: AB Ülkeleri İle Bir Karşılaştırmalı Bir Analiz”, Sosyoekonomi, Vol. 25(33), 195-220.

\begin{tabular}{|c|c|c|}
\hline \multirow[t]{2}{*}{ Hollanda } & 2009 & $\begin{array}{l}3 \text { aylık ödenek için işsizliğin ilk gününden önceki } 36 \text { hafta içinde en az } 26 \text { hafta istihdam edilmek gerekmektedir (haftalık } \\
\text { koşul). } \\
\text { İstihdamdaki aylara eşit olacak biçimde işsizlik ödeneği alabilmek için (en fazla } 38 \text { ay); işsiz kişi, işsizlikten önceki beş } \\
\text { takvim yılının dördünde en az } 52 \text { gün ücretli istihdam edilmelidir (yıllık koşul). }\end{array}$ \\
\hline & 2016 & $\begin{array}{l}3 \text { aylik ödenek için işsizliğin ilk gününden önceki } 36 \text { hafta içinde en az } 26 \text { hafta ücretli olarak çalışmak gerekmektedir. } \\
\text { İstihdamdaki aylara eşit olacak biçimde işsizlik ödeneği alabilmek için (en fazla } 38 \text { ay) işsiz kişi, işsizlikten önceki beş } \\
\text { takvim yılının dördünde en az } 208 \text { saat ücretli olarak istihdam edilmelidir (yıllık koşul). }\end{array}$ \\
\hline \multirow[t]{2}{*}{ Avusturya } & 2009 & $\begin{array}{l}\text { Son } 24 \text { ayda, en az } 52 \text { haftalık sigortalılık süresi; } 25 \text { yaşın altındaki işsizler için son } 12 \text { ayda } 26 \text { haftalık sigortalılık süresi } \\
\text { gerekmektedir. }\end{array}$ \\
\hline & 2016 & Koşullarda değişiklik olmamıştır. \\
\hline \multirow{2}{*}{ Polonya } & 2009 & İşsizlik kaydından önceki 18 ay boyunca en az 365 takvim günü, ücretli statüsü ile istihdamda geçmelidir. \\
\hline & 2016 & Koşullarda değişiklik olmamıştır. \\
\hline \multirow{2}{*}{ Portekiz } & 2009 & $\begin{array}{l}\text { İşsizliğin başlamasından önceki } 24 \text { ay içinde en az } 450 \text { gün istihdamda edilmiş olmak ve prim ödemek veya piyasadan } \\
\text { dışlanmak gerekmektedir. }\end{array}$ \\
\hline & 2016 & $\begin{array}{l}\text { İssiz kalmadan önceki } 24 \text { ay içinde en az } 360 \text { gün istihdam edilmiş olmak ve prim ödemek veya piyasadan dışlanmak } \\
\text { gerekmektedir. }\end{array}$ \\
\hline \multirow{2}{*}{ Romanya } & 2009 & İşsizlik kaydından önceki 24 ay boyunca en az 12 ay katkı yapmak gerekmektedir. \\
\hline & 2016 & Koşullarda değişiklik olmamıstır. \\
\hline \multirow[b]{2}{*}{ Finlandiya } & 2009 & $\begin{array}{l}\text { Bağımlı çalışanları (işçiler): Son } 28 \text { ayda en az } 43 \text { hafta istihdam edilmek ve her hafta en az } 18 \text { saat çalışmak gerekmektedir. } \\
\text { Bağımsı çalışanlar: Son } 48 \text { ayda en az } 24 \text { ay girişimci olarak çalışmak gerekmektedir. }\end{array}$ \\
\hline & 2016 & $\begin{array}{l}2012 \text { yılı için: Bağımlı çalışanlar: Son } 28 \text { ayda en az } 34 \text { hafta istihdam edilmek ve her hafta en az } 18 \text { saat çalışmak } \\
\text { gerekmektedir; } \\
\text { Bağımsız çalışanlar: Son } 48 \text { ayda en az } 18 \text { ay girişimci olarak çalışmak gerekmektedir } \\
2015 \text { ve } 2016 \text { yılları için ise; Bağımlı çalışanların; son } 28 \text { ayda en az } 26 \text { hafta ve her bir hafta için en az } 18 \text { saat çalışmak } \\
\text { gerekmektedir; } \\
\text { Bağımsız çalışanlar: Son } 48 \text { ayda en az } 15 \text { ay girişimci olarak çalışmak gerekmektedir. } \\
\text { Gelire bağlı işsizlik ödeneğinden yararlanabilmek için: "Temel işsizlik ödeneği"nin ve bir işsizlik fonunun üyesi olarak } \\
\text { istihdam halinde iken zorunlu sigortalılık süresinin tamamlanması gerekmektedir. }\end{array}$ \\
\hline \multirow{2}{*}{ Lüksemburg } & 2009 & İstihdamdaki son 1 yıl boyunca, en az 26 hafta katk1 yapmak gerekmektedir. \\
\hline & 2016 & Koşullarda değişiklik olmamıştır. \\
\hline \multirow{3}{*}{ Slovakya } & 2009 & Son 4 yıl yılda, en az 3 yıl (geçici çalışanlar için 2 yıl) işsizlik sigortası katkısı yapmak gerekmektedir. \\
\hline & 2016 & $\begin{array}{l}\text { Son } 3 \text { yılda en az } 2 \text { yıl işsizlik sigortası katkısının ödenmiş olması gerekmektedir (geçici çalışan işçilerde bu durum } 4 \\
\text { yıldır). }\end{array}$ \\
\hline & 2016 & $\begin{array}{l}\text { Yukarıdaki kazanca bağlı işsizlik sigortasından yararlanma koşuluna ek olarak, işsizin başvurusunda işsizlik sigortası } \\
\text { fonunun kapsamındaki uygulamalara katıldığını ispat etmesi gerekmektedir. }\end{array}$ \\
\hline \multirow[b]{2}{*}{$\begin{array}{l}\text { Birleşik } \\
\text { Krallık }\end{array}$} & 2009 & $\begin{array}{l}\text { İşsizlik sigortası ödenekleri katkı tabanlı iş arayan ve gelir tabanlı iş arayanlar için farklı koşullarla belirlenmiştir. } \\
\text { Katkı tabanlı iş arayanların ödenekleri: } \\
\text { Süre ile ilgili bir koşul yoktur ancak katkı payları ödenmelidir. } \\
\text { Gelir tabanlı iş arayanların ödenekleri: } \\
\text { Süre ile ilgili bir koşul yoktur ancak işsizin Birleşik Krallık'ta ikamet etmesi gerekmektedir. }\end{array}$ \\
\hline & 2016 & $\begin{array}{l}\text { Katkı tabanlı iş arayanların ödenekleri: } \\
\text { Süre ile ilgili bir koşul yoktur ancak katkı payları ödenmelidir. } \\
\text { Katkı payı, iki vergi yılının birinde, o yıl için haftalık katkı temel miktarın en az } 26 \text { katı olmalıdır ve katkı payı veya henüz } \\
\text { alınmamış pay, ardışı iki vergi yılının her biri için, haftalık katkı toplam miktarın en az } 50 \text { katı olmalıdır. } \\
\text { Gelir tabanlı iş arayanların ödenekleri: } \\
\text { Süre ile ilgili bir koşul yoktur ancak işsizin Birleşik Krallık'ta ikamet etmesi gerekmektedir. } 1 \text { Ocak } 2014 \text { tarihinde işsizlik } \\
\text { sigortası talebinde bulunan kişinin üç aydır Birleşik Krallık'ta yaşadığını ispat etmesi gerekmektedir. }\end{array}$ \\
\hline \multirow[t]{2}{*}{ İrlanda } & 2009 & $\begin{array}{l}\text { Sigortalı } 104 \text { haftalık katkı payı ödemelidir; yardımdan önceki yılda ise } 39 \text { haftalık prim veya en az } 13 \text { kez prim ödemelidir. } \\
\text { Daha sonraki sigorta yardımlarında, yardımdan önceki diğer bazı yıllarda yapılan katkılar veya } 2 \text { vergi yılının her biri için } \\
26 \text { haftalık katkı yapmak gerekmektedir. }\end{array}$ \\
\hline & 2016 & Koşullarda değişiklik olmamıştır. \\
\hline \multirow{3}{*}{ Hirvatistan } & 2009 & - \\
\hline & 2015 & İstihdamdaki son 24 ay boyunca 9 ay prim ödenmelidir. \\
\hline & 2016 & Koşullarda değişiklik olmamıştır. \\
\hline
\end{tabular}

* Açılamalar 2009 ve 2016 yılının yedinci ayını kapsamaktadır.

Kaynak: MISSOC, Comparative Tables Database 2009, 2014, 2015, 2016. 